\title{
Catching-up Industrial Development of East Asian Economies and its Application to Vietnam*
}

Ngo Trinh Ha

Feb. 2004

Doctoral Course, Graduate School of Asia-Pacific Studies Waseda University

Email: k01s304@wiaps.waseda.ac.jp

\begin{abstract}
This paper attempts to examine the catching-up process in industrial development of East Asian economies. For this purpose, RCA curve will be used to depict this process and Spearman's rank correlation coefficient will be employed as a supporting evidence for the catching-up.

The paper shows that the evolving specialization patterns of East Asian economies are in accordance with the prediction of Catching-up Product Cycle (CPC). The specialization patterns of these economies differ according to their level of development. Japan has the most advanced industrial structure, followed by Korea, Taiwan, Singapore, and Hong Kong which have middle advanced industrial structures consisting of production of laborintensive, capital-intensive and technology-intensive goods; the older members of ASEAN - Thailand, Malaysia, the Philippines, and Indonesia, and are trying to catch-up in industrial development with NIEs by industrial upgrading. More interestingly, the paper finds that the industrial structures of these economies evolve overtime, from the pattern of a late industrializing economy to that of an intermediate country, and to that of an advanced country. The paper also shows that the late-industrializing economies follow in the footsteps of early industrializing ones and that there exists a unique interdependence linkage. This creates the dynamism of the region.

The results suggest that the late industrializing can short cut the industrial development by following in the footsteps of the early industrializing economies. The paper finds that Vietnam began joining the regional network. However, the industrial and trade policy have been impeding the industrial development of the country so that the laborintensive production has been untapped, on one hand, and Vietnam selected the 'wrong' targeted industries on the other hand.
\end{abstract}

\section{Introduction}

One of the major characteristics of East Asian economic development was the rapid industrialization. The domestic production and trade structure of East Asian economies has been making remarkable changes from the introduction of modern industries originated from the more advanced economies to the periods of exports. The specialization pattern evolved from the simple industries to more sophisticated industries. This industrial

\footnotetext{
* Grateful acknowledgements are due for the guidance and comments of Professor Ippei Yamazawa. Helpful comments from Professor Shujiro Urata, Professor Tran Van Tho, Professor Yoshiaki Abe are also acknowledged. The author is also indebted to Mr. Yosuke Noda, IDE for his kindness of obtaining the trade data in this study. Any errors are the responsibility of the author.
} 
upgrading, which had been observed in most economies in the region, created the rapid economic development. Japan became the second biggest economy in the world, Korea, Hong Kong, Singapore, and Taiwan became Asian NIEs, and other countries such as Thailand, Malaysia , the Philippines, and Indonesia also have been following suit and catching-up with those ahead.

There has been a strong belief that the interaction among trade, FDI and production is the key to this remarkable change (Yamazawa 1990, Kosai and Tran 1994, Blomqvist 1996, Dowling 2000, Parker 2002, Urata 2002, Hiratsuka 2003,). They insist that international trade helps late-industrializing economies to become exposed to the modern industries, therefore the modern industries emerged owing to the strong pursuit of FDI that gives them a great capacity for structural change and allows their economies to develop rapidly.

The rapid industrialization in the region could provide implications for the lateindustrializing economies such as Vietnam, Cambodia, Laos, and Myanmar etc. The insights, thus, needed to be identified. Various theories can be used to trace out the insights. They consist of comparative advantage theory by Ricardo, Heckscher-Ohlin model and the Catching-up product cycle (CPC) model. However, the success story of East Asian shows strong evidence of close links among changes in specialization patterns and FDI so that the CPC, which describes the linkage among trade-FDI and production is the most powerful tool to address. According to the CPC, the economies are involved in a multi-tiered 'catching-up' industrialization in line with comparative advantage. Japan, the early industrializing economy leading East Asian economies known as the flying geese formation, is the country that has the others join the flock by moving the industries that she has no longer competitive edge to the next tier through the expansion of trade and FDI. The process is continuously repeated so that the structural changes have been often observed in the region creating rapid development.

Despite there are quite a lot of studies on the catching-up in industrial development of NIEs, and ASEAN 4- Thailand, Malaysia, the Philippines, and Indonesia, there are no existing empirical studies that mention the fourth tier of the flock, that is the new members of ASEAN. This paper examines the catching-up in industrial development of the earlyindustrializing economies (Japan, NIEs, ASEAN4) and its application to Vietnam. The paper is structured as follows: its theoretical framework is reviewed and discussed in section 2. Section 3 contains the review of existing empirical studies. This is followed by the empirical analysis, where the revealed comparative advantage index and Spearman's rank correlation coefficients of RCA index are analyzed in order to identify the evolution of specialization pattern and catching-up of economies in the region. Section 5 applies the analysis to Vietnam to see whether Vietnam joined the flying geese formation. Section 6 analyzes the effects of trade and industrial policies of Vietnam to see how these policies affect the catching-up process. The section 7 concludes the paper. 


\section{Theoretical framework}

The law of comparative advantage was originated by David Ricardo in his work, the Principle of Political Economy and Taxation (1817), which states that specialization and trade pattern are, to some extent, determined by differences in autarky prices. Ricardo argues that international trade does not require different absolute advantage and that it is possible and desirable to trade when comparative advantage exists whenever the relative labor requirement differs between the two commodities. This specialization, determined by comparative advantage, enhances the efficiency of the resource use and increases the well being of all. One country’s specialization is shaped by its comparative advantage.

The two country-one factor model of David Ricardo that was influenced by the fact that labor is the most important factor in production, is not applicable to explain current changes in comparative advantage.

Besides the law of comparative advantage by Ricardo, 2x2x2 Heckscher-Ohlin model has been useful to explain the specialization pattern of economies. The theory provides a deeper understanding of the critical factors underlying cost differences and therefore comparative advantage. It figures out that comparative advantage is determined by the nation's resources (labor, and capital). The model is based on the interaction between production and trade. The difference between $\mathrm{H}-\mathrm{O}$ model and the Ricardo model is that H-O model includes another factor - capital to explain how the capital accumulation determines the diversification of industrial structure.

Individual industries differ in their factor intensity. Labor-intensive industries require more labor where capital-intensive ones require more capital. The capital accumulation will lead to the fact that ratio of capital to labor is higher than it was before the return to labor, thus, is relatively lower than that to capital, the production, therefore, will shift to capital-intensive industries.

The 2x2x2 H-O model has several limitations. First, the model restricts its relevance to the real world situation, where many countries trade many commodities, which are produced by using different factors of production. If one economy produced only two commodities, then not much dynamic growth via industrial upgrading in East Asia would have bee realized. Another shortcoming is that assumptions of the model are strict. For instance; assumptions of labor and capital immobility among economies, no impediments for trade, constant returns to scale and identical technologies are hardly valid for the real world situation.

The flying geese model, which was renamed as Catching-up Product Cycle after Kojima (1973) associated it with the product cycle model of Vernon (1964), was advocated by Akamatsu in 1941 originally focused on Japan's development of modern industries. A typical development pattern of modern industries includes the introduction of a modern 
industry through import, domestic production to substitute imports and finally exports. The model is also the one to describe the interaction between trade and production.

The model was further developed by Yamazawa (1990, 1993). The development process of one modern industry was empirically studied by Yamazawa who further identifies 5 stages of the process (Yamazawa 1990): introductory stage, import substitution stage, export stage, mature stage, and reverse import stage. The model, after developed, consists of three different varieties. First it can be used to address the development over time of one industry through 5 phases. Second, industrial structure of one economy evolves over time. And third, it can be used to show the interdependence between different countries with different levels of development where the transfer of one industry will be made from the more to less advanced economy whenever the fall of industries occurs.

In addition, both Kojima and Yamazawa share a common finding that the interaction between FDI and production patterns is an important factor that let countries develop in an orderly manner, making those economies more and more interdependent. According to the model, an industry emerges, rises, and falls in a group of economies in an order determined by dynamic comparative advantage in each economy. The dynamic comparative advantage can be defined as the potential comparative advantage one country will have, but not yet realized. The industry rises first in the more advanced economy, and after it grows for a certain period of time, it falls because of the high cots production in comparison with the costs in other industries. As a matter of fact the industry needs to find its own efficient site. The industry will be moved to another country, which offers lower cost of production and the import substitution. FDI facilitates this process so as to move the falling industry from more advanced to less advanced economies, this process is continuously repeated so that if one country's industrial structure is examined, the structures of economies at different levels of development will differ, structures of those at similar levels of development will look identical.

\subsection{CPC and three typical production and trade structures}

The H-O model explains how capital-intensive goods production expands, that is, how the industrial structure is diversified so that accumulated capital is fully employed. But if capital-intensive industries are disaggregated, there will be industries that require much capital but not much technology, while others require moderate amount of capital but much technology. 'The accumulation of capital provides a primary explanation for broad diversification of industrial structure, but it must be supplemented by additional factors affecting actual diversification at more disaggregated level. The CPC model meets this need (Yamazawa 1993)'. While the H-O model in particular, and neoclassical theories in general emphasize the capital factor as an engine to shift the industrial structure toward the capital-intensive industries, the CPC, new $\mathrm{H}-\mathrm{O}$ model, new growth theory emphasize technology as a key factor. 
The CPC is dynamic, while other neo-classical models are based on comparative statics. The rise and fall of industries are determined by their competitive edge. The variation 1 of the model implies that the production structure evolves overtime in one country from the simple production to more sophisticated production. Figure 1 illustrates the evolution by means of three RCA curves: A, B, C. The shape of RCA curve depicts the specialization pattern reflecting one country's industrial structure. Changes in specialization pattern overtime, thus, reflected by the shifts of RCA curve. .

The RCA curve shows values of revealed comparative advantage index for 5 broad groups of commodities ordered by their factor intensity: natural resource, petroleum, laborintensive, capital-intensive, and technology-intensive products. The RCA curve is used for the purpose of illustration, since there is a limit of using broad classifications. The vertical axes shows values of revealed comparative advantage index proposed by Balassa, while the horizontal axes represents the commodities. Curve A represents the specialization pattern of a late-industrializing economy having a comparative advantage in natural resource intensive products, and labor-intensive products. Curve B shows the specialization pattern of the intermediate economy having a comparative advantage in manufactures such as labor-intensive, capital-intensive products. Curve $C$ represents the specialization pattern of the advanced economy with a comparative advantage in technology-intensive products.

At the early stage of development, one economy's comparative advantage relies mainly on natural resources and its labor. This economy specializes in natural-resourceintensive and labor-intensive goods production. The natural resource and labor will tend to be put into full use so as the industrial structure becomes more diversified.

At later stage, four forces affect the diversification of industrial structure (Yamazawa 1993). They are the increasing availability of capital, the entrepreneurship, forward and backward linkage effects, and the learning effect.

The increasing availability of capital sourced from domestic capital accumulation and FDI. This is different from $\mathrm{H}-\mathrm{O}$ model in the sense that capital is not only mobile within one economy but also internationally mobile. According to the $\mathrm{H}-\mathrm{O}$ theorem, the increasing availability of capital makes the return to labor lower so that the country becomes more expensive to produce natural-resource intensive and labor-intensive products. The country tends to move toward capital-intensive goods production. The $\mathrm{H}-\mathrm{O}$ factor proportion theory is the primary foundation to explain the mechanism of structure changes in specialization in the process of industrialization.

The H-O model explains how the capital-intensive goods production expands, so that the increased capital can be fully used. Yet, the world is more complicated if we break up industries and try to explain the actual process of industrial upgrading, we have to distinguish different forms of capital and technology specific to individual industries. That means the change in production and trade structure cannot be determined by the full employment condition alone. 
The entrepreneurship is another force to decide the start of a new industry. The entrepreneur's decision is based on expected values of the domestic demands, protection, decreasing costs and his experience. In Japan, as proved by Yamazawa (1990) that Japanese trading companies advised their manufacturers in which directions their comparative advantage would shift.

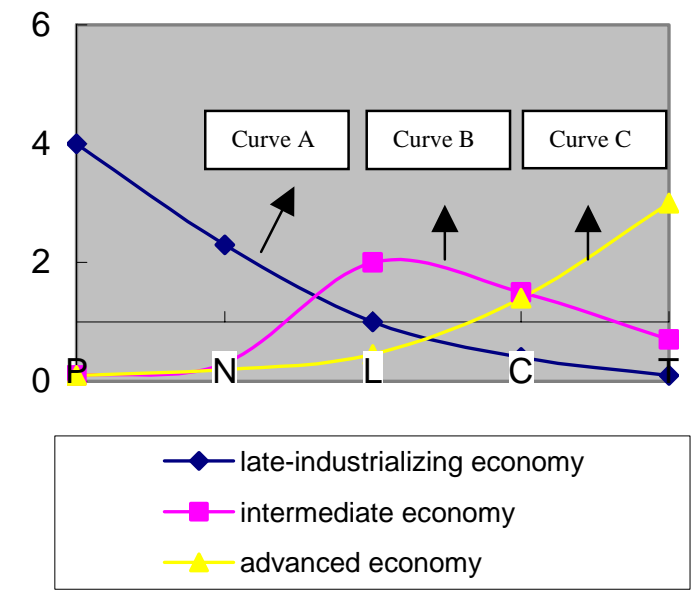

Figure 1 Three economies

at three levels of development

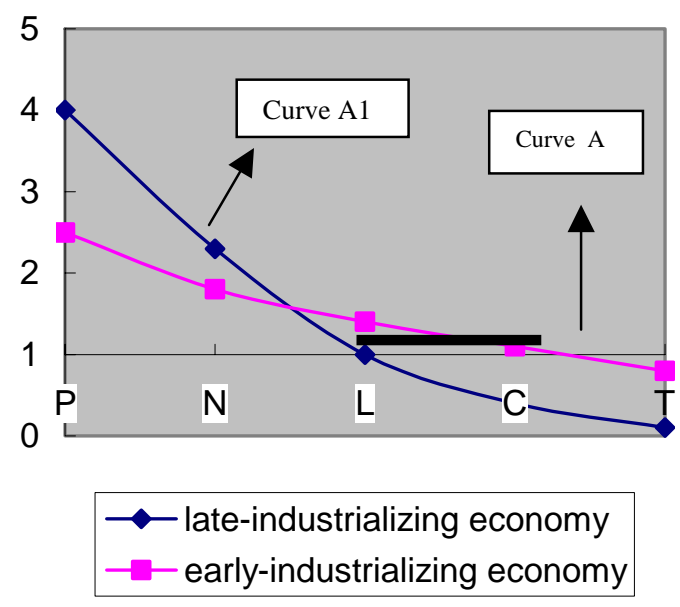

Figure 2 Two economies

with similar factor endowments

Source: author

Note: P: petroleum, N: natural-resource intensive products, L: labor-intensive products, C: capital-intensive products, T: technology-intensive products.

The backward and forward linkage effects assisted the spread of CPC from the first to other industries. In the forward linkage industries inputting the first industry's output is assisted to follow the CPC while in the backward linkage industries supplying input the first industry is encouraged by the increasing demand.

Finally, the learning effect helped the spread of one industry's CPC to the other. At first, the concerned economy will tend to use the simple or standardized technology, then gradually being able to master more sophisticated technology. This helps one economy to upgrade from capital-intensive goods production to technology-intensive goods production.

The model describes the continuous changes in industrial structure in economies at different stages of development. The changes are first reflected by the increasing competitiveness of one industry over a certain period of time, or the outward shift of curves in figure 1. Along with the improved factor endowments, the country might find that the production of the industry becomes more expensive. The industrial structure is upgraded toward capital-intensive production. However, owing to other factors such as 
entrepreneurship, backward and forward linkage effects, learning effect, the industrial structure will be upgraded toward more sophisticated production such as the production of technology intensive goods.

\subsection{CPC and dynamic comparative advantage}

The spread of CPC from one country to another is explained by the basic type of CPC repeated by late-starting countries with less capital endowment. The process is facilitated by the transfer of managerial resources from the early industrializing to the late industrializing country. The industry that is no longer competitive in the early industrializing economy will move to the late industrializing economy to maintain a competitive edge. This movement is continuously repeated so that the present specialization structure of the early industrializing economy will be basically that of the late industrializing economy in the future. This is the prediction of dynamic change in comparative advantage based on the CPC model.

The countries at the same stage of development tend to have similar industrial structure, that is, they are competitive with each other rather than complementary. On the other hand, those at different stages tend to have different industrial structures, and that is, they are complementary rather than competitive. Hence, the less developed ones follow the more advanced ones to develop. In other words, the dynamic comparative advantage would give practical implications for the less developed economies.

The CPC is based on the H-O model. The differences among the two are dynamics versus statics, detailed versus general prediction, applicable assumptions versus strict ones. The first difference has been described earlier as that the CPC does not only predict the current specialization pattern but it also predicts the 'future' trend. The second is that while the $\mathrm{H}-\mathrm{O}$ model states the specialization pattern depends on the concerned country's factor endowment, the CPC gives a more detailed prediction that one country at the early stage of development has specialization pattern of natural resource intensive products, and she gradually upgrades the industrial structure as analyzed above. The third difference is their applications to the real world. In CPC, there exists no strict assumptions, capital and labor can be mobile, and impediments can exist. Neo-classical theory assumes that there exists no mobility of factors of production across national borders. In the framework of flying geese pattern, physical and human capital from the declining industries in early industrializing economies streaming down to the late-industrializing economies are embodied in the form of FDI, a channel to maintain the competitive edge of one industry in stead of closing down the industry. In this sense, FDI is a very important factor to upgrade one's industrial structure, once the economy industrializes with a little capital endowment.

Though comparative advantage reveals the specialization pattern of one country at a certain time, it does not provide us with any prediction for one country's future specialization pattern. However, based on the CPC, prediction of potential comparative advantage can be traced out. This is the difference between revealed comparative advantage 
and potential comparative advantage. Potential comparative advantage is actually the dynamic analysis of comparative advantage. CPC is a good tool to apply to the dynamic analysis.

The figure 2 shows the RCA curves of two countries with similar factor endowments but one industrializes earlier than the other. Curve A represents the country A that is an early industrializing economy endowed with natural resources and unskilled labor, which has a comparative advantage in labor-intensive, and possibly capital-intensive products. Curve A1 represents the country, which is a late-industrializing economy with similar factor endowments to the country A, but with a skewed comparative advantage in natural resource products reflecting weak competitiveness in labor-intensive industries. Along with the development, country A will accumulate both physical and human capital. The increasing availability of capital will make the return to labor lower than it was before (H-O theorem), this makes the country a more expensive production site of labor-intensive products and a cheaper production site for up stream and capital-intensive industry. The entrepreneurs of country A will choose to relocate the uncompetitive industry and start new industries. The uncompetitive industry will be relocated in the country that has cheap labor and available natural resources. On the other hand, for the late-industrializing country A1, it really wants to industrialize the economy, but it is short of managerial resources such as capital, technology etc. This country would accumulate capital and technology by itself if the economy were closed and there existed no labor, and capital mobility. However, we are living in a globalization era, the factors such as capital and technology can be quickly transferred through the channel of FDI. Thus, country A1 will be able to accelerate its industrialization by importing managerial resources from aboard rather than generating and accumulating locally. These two countries, A and A1 can go to a good deal in which A is willing to locate the uncompetitive industry in A1, and A1 is greatly willing to accept it. There is no reason that these two countries reject the deal. Furthermore, the early industrializing economy will invest in the late-industrializing one so that the late industrializing will follow suit with the early industrializing country in terms of specialization patterns. Look at the figure 2, the bold area on the horizontal line implies the dynamic comparative advantage. In other words, this area indicates the commodities in which country A1 will potentially have a comparative advantage. Similarly we can derive the RCA curves for two intermediate economies and two advanced countries. This is the dynamics of the CPC.

The CPC that incorporates trade, FDI, and production appears to be a useful analytical framework for addressing industrial development of individual economies in the context of regional economic interaction among a group of countries, especially when these are at different levels of development. In addition, according to the CPC model, the government intervention might contribute to the catch-up process under the form of importsubstitution and export-promotion. Especially in the early phases of qne industry's rise, government's trade and industrial policies can be applied to accelerate the introduction of the industry as well as to enhance the capacity of export expansion through increasing the 
competitive edge of that industry. In the late phase of reverse import, the government may slow down the process by trade policies.

The flying geese pattern or CPC has been shown as a powerful tool to address the catching-up in the region and the dynamic comparative advantage. The CPC could provide good implications for the late-industrializing economies.

\section{Review of existing empirical studies}

Studies on dynamic structural changes in Asian economies, especially the shift in comparative advantage from Japan to the next tier of the flying geese flock, NIEs, and from NIEs to other late-industrializing countries in the region have mushroomed recently (Kosai and Tran 1994, Dowling and Cheang 2000, Parker, 2002, James and Movshuk, 2003, Hiratsuka 2003). Consistently strong evidence has been found that comparative advantage shifted from one industry to another industry (Yamazawa 1993, Kosai and Tran 1994, Dowling 2000). The evidence that NIEs countries are catching up with Japan has been shown by James 2003. However, how the ASEAN members, especially the late industrializing countries such as CLMV's catch-up with those ahead has not yet been studied.

The RCA and specialization index are often used to analyze changes in comparative advantage and competitive edge of industries, specialization patterns, and structural adjustments in production (Dowling and Cheang 2000, Parker 2002, James and Movshuk 2003, Hiratsuka 2003). The Spearman's rank correlation coefficient of RCA is also widely employed to analyze the similarity among countries (Dowling and Cheang 2000, James and Movshuk 2003). Thus, the RCA and Spearman's rank correlation coefficient can be employed to analyze the catching-up, the specialization patterns at different stages of economic development.

Strong evidence found that there were shifts in comparative advantage from Japan to NIEs, and that NIEs became more competitive within themselves (James and Movshuk 2003), and their specialization patterns become more similar with Japan. However, there is still short of studies expanding the scope to ASEAN, especially to its new members, though Dowling and Cheang expanded the study scope, the expansion reaches the four older members of ASEAN- Indonesia, Malaysia, the Philippines, and Thailand.

Evidence to identify the links between trade and FDI is also found (Yamazawa 1990, Kosai and Tran 1994, Dowling and Cheang 2000, Urata 2002). Japan is put on the focus of these studies. Japan's FDI and technology are considered as Japan inputs for the lateindustrializing countries to upgrade industrial structure. The evidence found that Japan inputs are present in the industrialization of the NIEs, and ASEAN 4.

Numerous papers examine the catching-up process in industrial development of East Asia, whereas Japan as a leading country followed by NIEs, and ASEAN 4 (Yamazawa 1993, Dowling and Cheang 2000, James and Movshuk 2003, Hiratsuka 2003). 
The findings are described by the CPC model. Only three out of these studies test the catching-up process in all industries (Dowling and Cheang 2000, James and Movshuk 2003, Hiratsuka 2003), while three of them covers almost countries in the region (Yamazawa 1993, Dowling and Cheang 2000, Hiratsuka 2003). The findings in these studies are consistent with the CPC model.

Hiratsuka (2003) tries to link changes in FDI, trade patterns. He found that the shifts in competitiveness take the prediction of the CPC in which Japan, a forerunner is flying in front of all the groups in East Asia, and followed by the second-tier-flying NIEs, and by the third tier-flying ASEAN and a new flyer-China, and by the fourth-tier-flying new members of ASEAN. One of strong points in Hiratsuka's study is that the graphic presentation, that shows a great advantage of how the countries catch up with each other in industry by industry. Yet, the international competitiveness coefficient (ICC) that is used in his study, might distort the 'real' comparative advantage. The ICC is calculated by dividing the difference of export and import of one commodity by the total export and import of that commodity. Yet, as there had been quite a lot of trade barriers imposed in East Asia in the 70s, imports tended to be controlled and be small, and thus the difference between export and import of one industry, especially of a targeted industry was rather larger. The calculation is heavily influenced by trade barriers.

Dowling, and Cheang (2000) also include the FDI in their analysis. They test whether the evolving trade and FDI patterns of Asian economies support the CPC. RCA and Spearman's rank correlation coefficient are analyzed to identify the dynamic changes in comparative advantage in East Asia. FDI ratios are calculated to identify the sectors that receive the most of Japanese FDI and evaluate its consistency with the CPC model. They also use the graphic presentation to show the detailed change in industry. It is found that the pattern of RCA for the NIEs and ASEAN 4 suggested that these economies have undergone substantial structural change, and the economic development trickled down from NIEs to ASEAN 4, and FDI data do lend general support for the trade and investment linkage.

James and Movshuk (2003) just focused on Japan, Korea and Taiwan. They try to analyze the changes in comparative advantage of these economies and the similarity over the period of 1980-1999. Though they do not directly mention the CPC model in the paper, their finding, which is the export pattern of Korea and Taiwan are converging with that of Japan, somehow supports the model in the sense that they follow suit the footsteps of Japan in industrial development.

In summary, though there have been quite a lot of studies on East Asian economies, new members of ASEAN have not been included in those studies. Do the new members join the regional dynamism? How the late-industrializing countries can catch up with the early-industrializing countries remains an unanswered issue. In order to answer these questions, the footsteps of the early industrializing economies need to be found. Based on these findings, the potential comparative advantage will be identified to be the center of the 
trade and industrial policies. This study will aim at examining the catching-up process in East Asia, and applying the CPC model to Vietnam's industrial development.

\section{Empirical Analysis of East Asian's Catching-up}

\subsection{Analytical framework}

The CPC model consists of a basic type and two varieties. First it can be used to address the development over time of one industry through 5 phases (Yamazawa 1990). Second if the industrial structure of one economy evolves over time. And third, it can be used to show the interdependence between different countries with different level of development where the transfer of one industry with the factors of production will be made from early-industrializing to late-industrializing economy whenever the fall of industries occurs.

The CPC is somehow similar to the well-known product cycle theory by Vernon in which it also describes the stages that one industry will experience. However, the key difference is that the description by Vernon model is to explain the development of one industry from the perspective of the advanced country, while CPC takes the perspective of the less-advanced economy (Yamazawa 1990, Dowling 2001). The basic theory of CPC model describes 5 phases that one industry would experience: introduction, importsubstitution, export, mature and reverse import. The basic one figures out how a new product is introduced from advanced countries to late-industrializing countries through imports. This stage corresponds to the export stage in the product cycle model. The next phase is that the concerned country accumulates the production technique via the interaction with trade so that it steps in production by herself, and be able to export. This stage corresponds to the declining stage of the 'product cycle' model.

The first variety of the CPC model addresses the evolving of industrial structure over time. The industrial structure changes over time along with the rising level of development. During one country's growth, thanks to the capital accumulation, forward linkage and backward linkage induced by availability of inputs and derived demand for output, new industry is set up so that we can observe that the industrial structure gradually shifts from production of natural-resource intensive products to the production of capitalintensive products, and to production of technology-intensive products. Typically, the lateindustrializing country will have the structure of natural-resource intensive goods production, and some of labor-intensive goods production. The intermediate country will tend to produce labor-intensive, and capital-intensive products. The advanced economy tends to produce technology-intensive products.

It might appear as if the industrial upgrading occurs naturally without any government interference. In fact, the experience from other forerunners in East Asia shows that the government interference through trade and industrial policies is quite critical. Policies can aim at protecting potential industries that are considered important to the 
economic development at the import-substitution phase (the second phase in the basic theory). CPC model would give us the ground to determine the potential industries. The next step is the job of the government to promote them by protecting these industries at their initial stage of development. However, a healthy dosage of competition from foreign producers should be allowed to make domestic stay cost efficient, and later, the protection can be released without any collapse of protected industries. If government protects declining and cost-inefficient industries, these industries will have no incentive to relocate. The trade and industrial polices, made by the government, cannot work if there is no consideration of the linkage with other countries in the region. The linkage is mentioned in the following part.

The second variety deals with the trade and FDI. The industries are spread from the early industrializing to late-industrializing economy, from Japan to NIEs, and then to ASEAN 4, then to new members of ASEAN. In this sense, we can see that all concerned countries can benefit from the transfer of industries. The late-industrializing countries upgrade industrial structure from the production of natural resource intensive goods to production of labor-intensive goods, while the intermediate countries can upgrade from the production of labor-intensive goods to capital-intensive goods and technology-intensive goods, and the advanced countries can be specialized in the production of technologyintensive goods. The first variety can provide us with the three specialization patterns reflected by three RCA curves. The region becomes more independent on each other for markets for their imports, and exports. The advanced countries will need to import from the late-industrializing countries, the products that no longer have competitive edge. On the other hand, the late-industrializing countries will be able to source the capital goods and technology to upgrade their industries through FDI flow from the advanced countries. That might confuse ones that the CPC model emphasizes the inter-trade industry. That would be the case, if there were no evolution of industrial structure. In fact, there, for sure some overlapping area of production that exists to create the intra-industry trade. This might be explained by saying that the intra-industry trade occurs due to the time lag that the industries would exist in the countries. Another good reason for that is the advanced countries actually upgrade their industrial structure, and now they specialized in the up stream-industry. The textile industry can be taken as a good example here, there are some segments that are labor-intensive, but there are also some segments that are capitalintensive. The advanced economy might graduate from the labor-intensive goods production and she is in the stage of production of the capital intensive ones. However, for the long-term convergence, the intra-industry trade tends to increase along with the evolution of industrial structure.

\subsection{Data description.}

One problem with determining the revealed comparative advantage (RCA) concerns data availability. The pattern of revealed comparative advantage would preferably be determined by using data about production, consumption, and trade. This is because RCA is ultimately a result of economic conditions, which determine the international pattern of 
comparative advantage. This pattern of comparative advantage, in turn, governs the pattern of trade, production, and consumption. However, my calculation is data-constrained. There is not much available data on production and consumption. Thus the RCA indices in this study will be derived from trade data only.

The data used in this study is attained from IDE database, the three-digit SITC, and compiled using the statistics of international trade by UN (various issues) for the period of 1970 to 1999, and compiled using the Vietnam's General Statistics Office data after making some changes to make the data consistent with those of IDE.

Aggregation of trade data is an issue of importance. The choice of a particular level of aggregation may lead to a distorted measure of the RCA. For instance, a country may massively produce high-quality finished steel in which it has a comparative advantage, but in order to meet input requirements it will import crude and semi-finished steel. A measurement of the RCA in industry level may not capture this effect. Thus it would be preferable to calculate RCA indices for broadly defined commodity groups. It is also very time consuming to calculate all specific commodities. It is more practical to study, first, aggregated groups of industries classification and then to focus on specific commodities of interest. The data are grouped in 5 categories covering 67 two-digit SITC items according to factor-intensiveness: petroleum $(\mathrm{P})$, natural-intensive products $(\mathrm{N})$, labor-intensive products (L), capital-intensive products $(\mathrm{C})$, and technology intensive products $(\mathrm{T})$. In fact, the $\mathrm{P}$ can be categorized in $\mathrm{N}$, however, $\mathrm{P}$ creates big amount of export earnings so that if we do that then the $\mathrm{N}$ will be distorted if the country in question has this natural resource.

The $\mathrm{P}$ and $\mathrm{N}$ seem likely to use natural resources intensively and the lateindustrializing countries are expected to produce and trade $\mathrm{P}$ and $\mathrm{N}$, and possibly some of the labor-intensive products due to the abundance of the associated resources including natural resources and labor. The 3 manufacturing groups - L, C, and T use capital, skilled labor and unskilled labor, and intermediate countries are expected to produce and trade $\mathrm{L}$ and $\mathrm{C}$, and possibly some of $\mathrm{T}$, and advanced countries are expected to produce and trade $\mathrm{T}$ intensively.

One problem concerns aggregations here is that aggregating in this study is productbased but not a process based one. The conclusion from the analysis of RCA might be incorrect if the aggregations are based on the product based method, since product-based RCA might reveal one country could have a strong comparative advantage in technologyintensive products, but in fact this country imports parts and components, and just assembles and does the labor-intensive jobs, then the country has a comparative advantage in the labor-intensive process. In order to have the process-based aggregations, we have to get 4 or even 6-digit SITC, and it is impossible to get the data, especially for the purpose of international comparison. Another way is that we look at the value added. This way is also very difficult because of data constraint and inconsistency between the trade data and production data. To solve this problem, the ratio $\mathrm{X}$ over $\mathrm{M}$ will be calculated. If one commodity has a strong RCA and high X over M (much more than one), we can conclude 
that the economy has a strong comparative advantage in the product and the process. On the other hand, if high RCA comes up with low X/M, we can conclude that the economy might import parts and components and just does the labor-intensive job. Yet, we must be cautious about the latter case since one economy might export the low quality products but import high quality products for their own tastes. Since no method can give a perfect answer, the paper adopts the latter method.

\section{RCA index}

Now I consider how to calculate RCA. Of several variants of RCA measure based only on trade data, I will consider two common types of measures:

- The first measure:

$$
\operatorname{RCA}_{i j}=\frac{\left(X_{i j}-M_{i j}\right)}{\left(X_{i j}+M_{i j}\right)}
$$

Where RCA $_{\mathrm{ij}}$ is the revealed comparative advantage index of country i' commodity j. $X_{\mathrm{ij}}$ is country i's export of commodity $\mathrm{j}$; $\mathrm{M}_{\mathrm{ij}}$ is country $\mathrm{i}$ 's imports of commodity $\mathrm{j}$;

The index ranges from -1 when there are no exports $\left(\mathrm{X}_{\mathrm{ij}}=0\right)$, which reveals comparative disadvantage, to +1 when there are no $\mathrm{M}_{\mathrm{ij}}$, which reveals comparative advantage

This index might be distorted by imports data since it is influenced by the import-substitution policies.

- The second measure: Balassa Index

$$
\operatorname{RCA}_{i j}=\left(\frac{X_{i j}}{X_{w j}}\right) /\left(\frac{\sum_{j} X_{i j}}{\sum_{j} X_{w j}}\right)
$$

Where $\mathrm{RCA}_{\mathrm{ij}}$ is the revealed comparative advantage index of country i' commodity j. $X_{\mathrm{ij}}$ is country i's export of commodity $\mathrm{j} ; \mathrm{X}_{\mathrm{wj}}$ is world's exports of commodity $\mathrm{j}$;

$$
\begin{aligned}
& \sum_{j} X_{i j} \text { is country i's total exports } \\
& \sum_{j} X_{w j} \text { is the world's total export }
\end{aligned}
$$


The index based on information about exports only. This so-called export performance ratio reveals a comparative advantage if country i's share export of 'world' exports of a certain commodity $\mathrm{j}\left(\frac{\mathrm{X}_{\mathrm{ij}}}{\mathrm{X}_{\mathrm{wj}}}\right)$ is greater than the country's share of world exports of all commodities, the RCA will be greater than 1 .

The omission of imports in this measure may prevent the index from distortion by the trade policies that often applied in the first phase of development of one industry.

\subsection{Empirical analysis}

The technique used in this paper is as follows: RCA indices for all 67 two-digit SITC are computed for individual countries for the period 1970-1999. To illustrate a broad specialization pattern of each country, I calculated RCA of 5 broad groups of commodities sharing similar factor intensity. Although it may sound a bold approach, it has worked well to illustrate different specialization patterns, as you will see in the following figures. In addition to the graphic presentation, the RCA indices for the top 20 of Japan's RCA in 1970 and 1999 provide information on changing structure of comparative advantage, thus, reflecting changes in specialization pattern in East Asian economies.

To identify the similarity/convergence in the region, the Spearman's rank correlation coefficients for each pair of countries' RCA vectors are being compared for the years 1970, 1975, 1980, 1985, 1990, 1995, and 1999. A negative or low positive coefficient indicates that the two countries' industrial structures are not similar, and they are complementary rather than competitive. On the other hand, if the two countries' industrial structures are similar, the Spearman's rank correlation coefficient will be positively large.

The Spearman's rank correlation coefficient is calculated by converting each variables to ranks and calculated by the following formula

$$
r_{s}=1-\frac{6 \sum d_{i}^{2}}{n\left(n^{2}-1\right)} \text { Where } d_{i}=\left(x_{i}-y_{i}\right)
$$

$x_{i}$, and $y_{i}$ represent the ranks of the $i^{\text {th }}$ pair of observations, $n$ represents sample size.

The Spearman's rank correlation coefficient has both advantages and disadvantages. The advantages of nonparametric procedures are, first, non parametric procedures can be used to get a quick answer about the similarity of two independent variables, second, for the big size of samples, Spearman's rank correlation coefficient shows a great advantage since it does not deal with the absolute values. However, the Spearman's rank correlation coefficient shows some disadvantages. The major disadvantage of nonparametric techniques is contained in its name. Because the procedures are nonparametric, there are no 
parameters to describe and it becomes more difficult to make quantitative statements about the actual difference between populations. In other words, the coefficient gives only the general trend of variables. The second disadvantage is that nonparametric procedures throw away information. Ranks preserve information about the order of the data but discard the actual values. Because information is discarded, nonparametric procedures can never be as powerful (able to detect existing differences) as their parametric counterparts when parametric tests can be used. For the test of East Asia, the coefficient will be unable to give the detailed changes in industrial structure. Third, the Spearman's rank correlation coefficient might be distorted by the size of economy. A small economy tends to have a comparative advantage in some selected commodities, the Spearman's rank correlation coefficient will not fully reflect the 'real changes'.

\subsection{Catching-up in East Asia: RCA curves and pattern of industrial development}

To test the pattern of industrial structures of East Asia, RCA curves will be shown over 1970, 1985, and 1999 and ranking RCA values to make the list of top 20 for RCA in 1970 and 1999. These lists provide insights of changes in specialization patterns in East Asian economies.

Japan

The graph in figure 3 in which the vertical axis shows the values of revealed comparative advantage indices of the commodities shown on the horizontal axis, indicates that Japan's specialization structure was upgraded from a pattern of an intermediate economy to that of an advanced economy as the country moved to the higher level of development. In 1985, Japan graduated from the labor-intensive goods production, and specialized in the capital-intensive goods production. Impressively, in 1999, she just specialized in the technology-intensive goods production.

In 1970, the technology-intensive and capital-intensive products were among the top ranked RCA values, and the ratios X over M were very high. However, in 1999, a remarkable change has been made that technology-intensive products are dominantly top ranked RCA values and their X over M ratios, though decrease, are still high. The telecommunication and sound recording apparatus products (SITC 76) has shown the strongest comparative advantage in her industrial structure over the period 1970-1990. In 1999 the top position was occupied by 
photographic apparatus, optical goods (SITC 88), and other technology-intensive products such as machinery equipment for industries (SITC 72), metal working machinery (SITC 73), electrical machinery, apparatus, and appliances (SITC77) etc. There was only one capital-intensive item that remains in the top ranked values: rubber manufactures (SITC 62), this indicates that Japan had graduated from labor-intensive, and capital-intensive goods production, and specialized in technology intensive production. However, it is worth noticing that the absolute indices have tended to decrease since 1990. This might be caused by the hollowing out when Japan firms moved their production sites to other countries due to the yen appreciation in 1985 and increasing labor-costs in Japan.

\section{NIEs}

All NIEs economies seem to have specialized in manufactures. They graduated from natural resource intensive goods production. They specialized in the labor-intensive and capital-intensive goods production over 1970-1985. In 1999, three of them including Korea, Taiwan, and Singapore shifted their structures toward capital-intensive and technology-intensive goods production shaping the specialization pattern of an advanced country.

Hong Kong and Singapore's dynamic change in structure is a bit different from Korea, and Taiwan's one, that might be explained by the unique feature in industrial policies implemented in Hong Kong, and Singapore. Singapore tends to leap over the laborintensive, and capital-intensive goods production because of strong government intervention to promote computers, and electronics to turn Singapore into a hi-technology manufacturing hub. As a result, the industrial growth in Singapore has been low for sometime. Hong Kong, on the other hand, tends to maintain comparative advantage in labor-intensive goods production. This reflects that Hong Kong has traditionally been a major exporter of textile and clothing (SITC65, SITC 84). Instead of further upgrading the industrial structure, Hong Kong chose to promote the service industry.

The specialization pattern of Hong Kong clearly shows that it maintained the specialization in labor-intensive, capital-intensive goods production over 1970-1999. One important finding is that though the industrial structure almost remained unchanged, the competitiveness tended to decrease. This might be explained by the government intervention that aims at turning Hong Kong into a financial hub for the region. In 1970, Hong Kong has a RCA structure heavily toward labor-intensive products. In 1985, the economy has a RCA structure relying on manufacture including labor-intensive, capital intensive, and technology-intensive production. However, in 1999, the economy shifted to technology-intensive, labor-intensive, and natural resource intensive products (Figure 4panel a).

Korea had the strongest comparative advantage in mainly labor-intensive products and other natural resource intensive products. However, until 1999, the labor-intensive 
products gave the way for the capital-intensive and technology-intensive products ${ }^{1}$. This finding is different from that of James and Movshuk. In that paper, the authors used the median to trace out the changes (figure 4-panel b).

Panel a: Hong Kong's RCA pattern

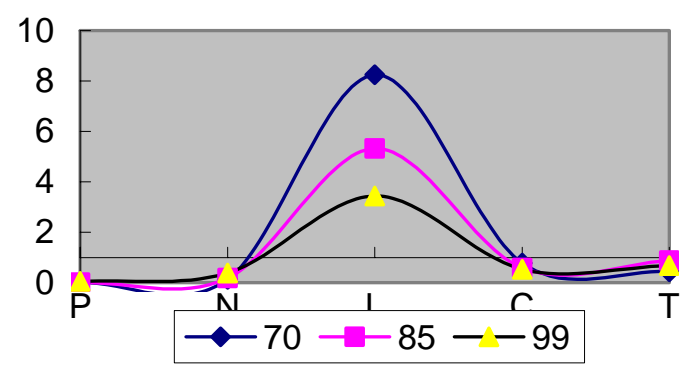

Panel c: Singapore's RCA pattern

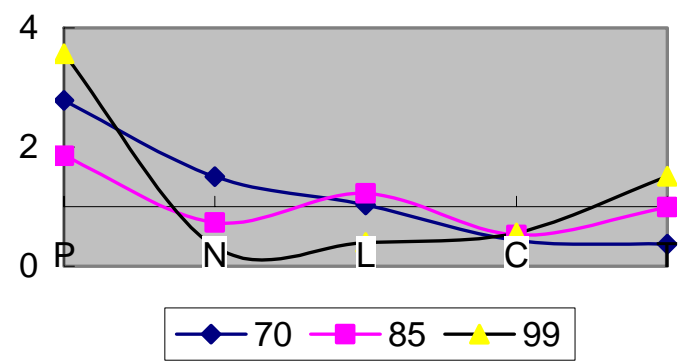

Panel b: Korea's RCA pattern

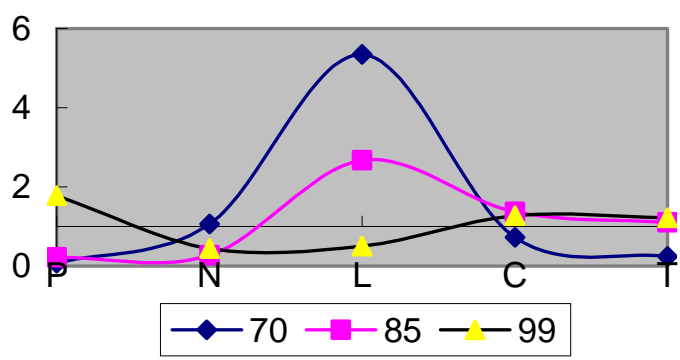

Panel d: Taiwan's RCA pattern

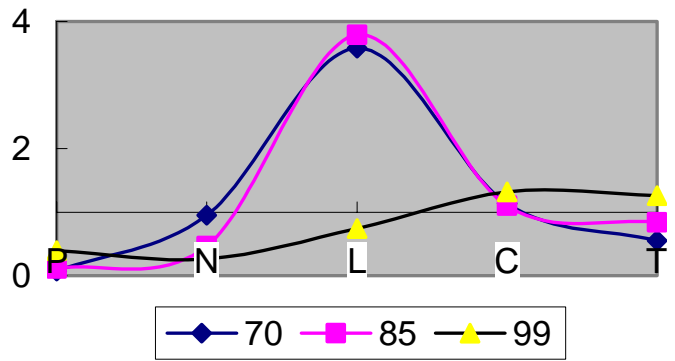

Figure 4 NIEs’ Industrial Development

Source: author

The pattern of Singapore is somehow different from Korea. In 1970, the pattern looked like the one of a late industrializing country in which it had a comparative advantage in natural-resource intensive products. The pattern has made a little change in which it has a comparative advantage in labor-intensive products in 1985 . However, Singapore had an ambition to move rapidly to the high-technology economy, by encouraging the computer, and electronic industry to develop, that is skipping over the labor-intensive goods production. In 1970 the comparative advantage relies on natural resource intensive and labor-intensive goods productions. In 1999, the technology-intensive and capital-intensive goods production occupied a majority of the top ranked RCA values (figure 4-panel c), that consisted of office machines and automatic data processing (SITC 75), electrical machinery, apparatus and appliances (SITC 77), telecommunication and sound recording apparatus (SITC76), photographic apparatus, optical goods (SITC88).

\footnotetext{
${ }^{1}$ It is worth noticing that the high $\mathrm{X}$ over M ratios of technology intensive products of Korea and Taiwan shows that these countries have been moving toward the advanced pattern of production.
} 
Taiwan's pattern has recorded a big change in which she specialized in laborintensive, and capital-intensive goods production over 1970, and 1985, and in 1999, she shifted toward capital-intensive and technology intensive goods production taking the shape of an advanced economy. In 1970, the economy had a RCA structure of natural resource intensive, labor-intensive, capital-intensive, technology-intensive products, of which the labor-intensive items accounted for the majority. In 1985, the structure remained almost unchanged. However, in 1999, there has a shift toward technology-intensive and capitalintensive products (figure 4-panel d).

\section{ASEAN}

Member countries of ASEAN 4 have recorded substantial dynamic changes. The Philippines and Indonesia's production patterns look similar as they devoted their efforts to diversify the labor-intensive goods production. Meanwhile, Malaysia and Thailand tend to upgrade their industrial structure toward technology-intensive goods production, which is similar to the policy implemented by Singapore.

Over the time, Indonesia still shows that industrial upgrading has been made. The RCA indices of natural resource intensive products tended to decrease while the manufacture tended to be higher. Natural resource intensive products: crude rubber (SITC 23), cork and wood (SITC 24), oil seeds and oleaginous fruits (SITC 22), fixed vegetable oil, fats and waxes (SITC 42) etc. were the major ones that showed strong RCA indices (figure 5-panel a). In 1999, only one L was added onto the list of top 10. However, a big change, that can be observed, is that the number of commodities, which have strong RCA indices, expanded, and the number of labor-intensive products increased, especially when looking at the top 20.

Malaysia's patterns in 1975 and 1980 took the shape of a late-industrializing country, but its pattern makes a quick change directly toward technology intensive goods production in 1999 due to the government intention to promote the electronics industry (figure 5-panel b). Over 1970-1985, the natural-resource intensive goods production was dominant among the top ranked RAC values. In 1999, Malaysia's structure of RCA and X over $\mathrm{M}$ ratio confirms that Malaysia made a similar shift toward the high-tech industries owing to the massive inflow of Japanese FDI to turn it to an advanced economy shape. Yet, despite the growing improvements of high-tech industries in RCA, there exists various natural resource based products that have strong RCA indices.

The Philippines's pattern was still at the level of a late-industrializing country in 1970, 1985, and 1999 (figure 5-panel c). In comparison with the pattern in 1970, there has been a big change in labor-intensive products. In 1970, the Philippines was the natural resource based economy since all commodities that showed a strong comparative advantage were all natural resource-intensive. In 1999, the structure was diversified, manufactured accounted for the majority of the list of top 10. Interestingly, on one hand, the Philippines seems to continue promoting the labor-intensive industry, on the other hand, she also 
promotes the technology-intensive goods production, that is why some of technologyintensive products are ranked among the top RCA values in 1999.
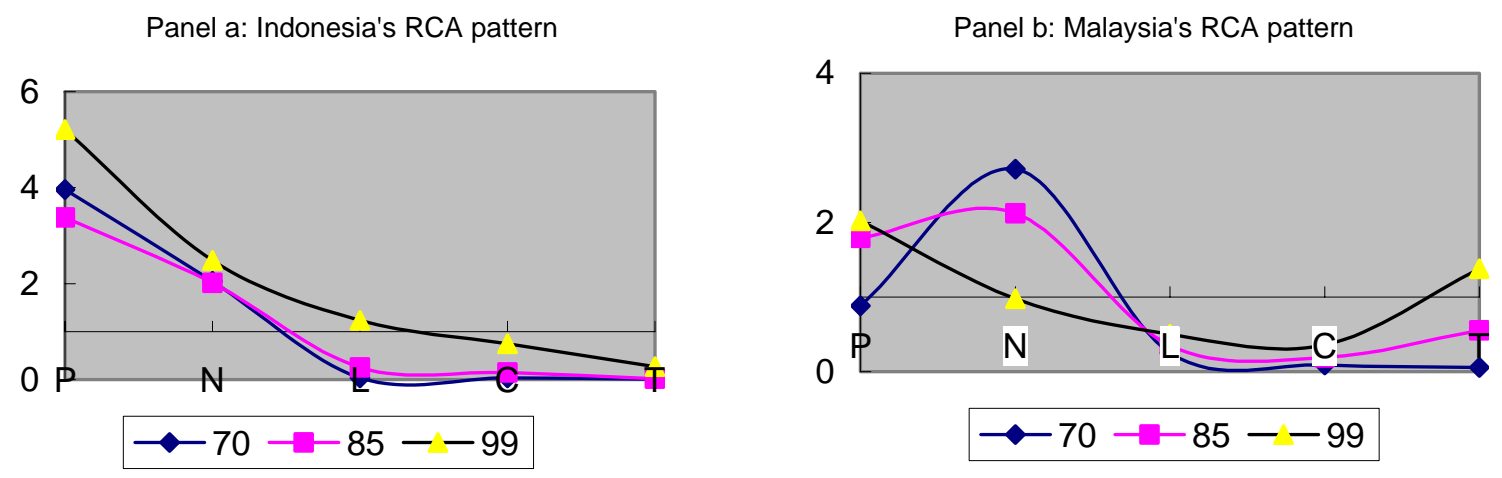

Panel c: The Philippines' RCA pattern

Panel d: Thailand's RCA pattern
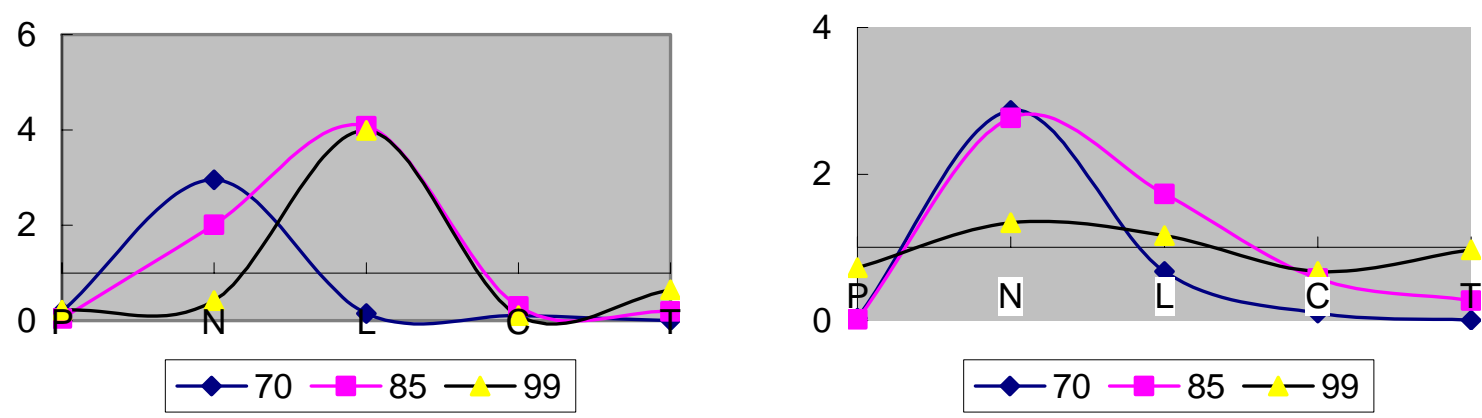

Figure 5 ASEAN's Industrial Development

Source: author

In 1970, similar to the Philippines, Thailand was a natural resource based economy. However, in 1999 the situation has been changed heavily toward the manufacturing industries (figure 5-panel d). Though natural resource based products were still the major ones of the top 10, the comparative advantage in manufactures has been improved. Technology-intensive products' RCA indices show great improvement so that they accounted a relatively big portion among top ranked RCA values, they are office machines and automatic data processing equipment (SITC 75), photographic apparatus, optical goods (SITC 88), telecommunication and sound recording apparatus (SITC 76), electrical machinery, apparatus and appliances (SITC 77).

\subsection{Statistical Tests of Export Similarity and Convergence}


Spearman's Rank Correlation Coefficients between Japan-NIEs

\section{Japan-NIEs}

The results indicated that Spearman's rank correlation coefficients (SRRC) between Japan-Korea, and Japan-Taiwan have been higher than those of the 2 others in NIEs. They are all increasing over the time indicating that those economies are trying to catch-up with Japan. Korea and Taiwan seems to be ahead of the 2 others.

Though significance convergence found for all 4 NIEs. Interestingly, even closer similarity between Japan's specialization pattern in 1970s and more recent pattern of Korea and Taiwan. In other words, Korea and Taiwan have been following suit with Japan's specialization pattern so that the rankings of these two countries became closer to that of Japan. Two pairs-Japan-Hong Kong, and Japan-Singapore slightly differ from those of two ahead-economies. The recent patterns of Hong Kong and Singapore are different from those of Japan in 1970s, and early 1980. This might be explained by the policies implemented by these economies that the former tries to maintain textile and clothing industry while the latter tries to promote technology-intensive industry skipping over laborintensive and capital-intensive industry. Although this implies that the two economies are not completely following in Japan' footsteps, they moved up the ladder and approach closer the pattern of Japan.

Table 1 Spearman's RCCs between Japan and Korea RCA indices

\begin{tabular}{llllllll}
\hline JPN-KOR & kor 70 & kor 75 & kor 80 & kor 85 & kor 90 & kor 95 & kor 99 \\
\hline \hline jpn70 & $\mathbf{0 . 4 6 8}$ & 0.528 & 0.679 & 0.761 & 0.807 & 0.780 & 0.740 \\
& $*$ & $*$ & $*$ & $*$ & $*$ & $*$ & $*$ \\
jpn75 & 0.319 & $\mathbf{0 . 3 0 0}$ & 0.499 & 0.607 & 0.720 & 0.758 & 0.755 \\
& $*$ & $*$ & $*$ & $*$ & $*$ & $*$ & $*$ \\
jpn80 & 0.253 & 0.245 & $\mathbf{0 . 3 6 7}$ & 0.565 & 0.649 & 0.593 & 0.611 \\
& $* *$ & $* *$ & $*$ & $*$ & $*$ & $*$ & $*$ \\
jpn85 & 0.202 & 0.241 & 0.320 & $\mathbf{0 . 5 2 7}$ & 0.618 & 0.561 & 0.596 \\
& & $* *$ & $*$ & $*$ & $*$ & $*$ & $*$ \\
jpn90 & 0.129 & 0.168 & 0.223 & 0.451 & $\mathbf{0 . 5 3 6}$ & 0.495 & 0.542 \\
& & & $* *$ & $*$ & $*$ & $*$ & $*$ \\
jpn95 & 0.116 & 0.114 & 0.154 & 0.412 & 0.522 & $\mathbf{0 . 5 8 1}$ & 0.635 \\
& & & & $*$ & $*$ & $*$ & $*$ \\
jpn99 & 0.082 & 0.094 & 0.137 & 0.367 & 0.493 & 0.558 & $\mathbf{0 . 6 1 5}$ \\
\hline
\end{tabular}

Source: calculated by author

Note: * significant at $5 \%$

** significant at $10 \%$ 
Table 2 Spearman's RCCs between Japan and Hong Kong RCA indices

\begin{tabular}{llllllll}
\hline JPN-HKN & hkn70 & hkn75 & hkn80 & hkn85 & hkn90 & hkn95 & hkn99 \\
\hline \hline jpn70 & $\mathbf{0 . 5 1 3}$ & 0.539 & 0.516 & 0.463 & 0.485 & 0.411 & 0.355 \\
& $*$ & $*$ & $*$ & $*$ & $*$ & $*$ & $*$ \\
jpn75 & 0.312 & $\mathbf{0 . 3 8 1}$ & 0.388 & 0.330 & 0.379 & 0.360 & 0.337 \\
& $*$ & $*$ & $*$ & $*$ & $*$ & $*$ & $*$ \\
jpn80 & 0.283 & 0.374 & $\mathbf{0 . 3 5 8}$ & 0.342 & 0.381 & 0.426 & 0.320 \\
& $*$ & $*$ & $*$ & $*$ & $*$ & $*$ & $*$ \\
jpn85 & 0.284 & 0.378 & 0.369 & $\mathbf{0 . 3 5 5}$ & 0.399 & 0.440 & 0.335 \\
& $*$ & $*$ & $*$ & $*$ & $*$ & $*$ & $*$ \\
jpn90 & 0.215 & 0.323 & 0.321 & 0.304 & $\mathbf{0 . 3 5 8}$ & 0.417 & 0.322 \\
& $* *$ & $*$ & $*$ & $*$ & $*$ & $*$ & $*$ \\
jpn95 & 0.151 & 0.245 & 0.265 & 0.242 & 0.285 & $\mathbf{0 . 3 8 3}$ & 0.408 \\
& & $* *$ & $*$ & $* *$ & $*$ & $*$ & $*$ \\
jpn99 & 0.125 & 0.226 & 0.255 & 0.222 & 0.284 & 0.389 & $\mathbf{0 . 4 2 5}$ \\
& & $* *$ & $*$ & $* *$ & $*$ & $*$ & $*$ \\
\hline
\end{tabular}

Source: calculated by author

Note: * significant at $5 \%$

** significant at $10 \%$

\section{NIEs-NIEs}

The results shows that the pair of Korea and Taiwan has the greatest correlation coefficients among pairs within NIEs, the correlation coefficients that have essentially zero $\mathrm{p}$ values indicate that the two countries' industrial structures are very similar and they are competitive with each other. Though other pairs show relatively high coefficients to say that they are relatively competitive, the coefficients for the pair of Hong-Kong and others tend to decrease over time (except the pair Hong Kong - Singapore). This, once again confirms that Hong - Kong has been moving its economy toward the service industry. Moreover, if we take a closer look at the pairs between Singapore with Korea, and Taiwan, we can find that Singapore has become more and more competitive with these economies since 1995. This is explained by the time lag of Singapore's policy toward the technologyintensive goods production.

Table 3 Spearman's RCCs between Korea and Taiwan RCA indices 


\begin{tabular}{|c|c|c|c|c|c|c|c|}
\hline KOR-TWN & twn70 & twn75 & twn80 & twn85 & twn90 & twn95 & twn99 \\
\hline kor70 & $\begin{array}{l}0.627 \\
*\end{array}$ & $\begin{array}{l}0.595 \\
*\end{array}$ & $\begin{array}{l}0.561 \\
*\end{array}$ & $\begin{array}{l}0.546 \\
*\end{array}$ & $\begin{array}{l}0.480 \\
*\end{array}$ & $\begin{array}{l}0.378 \\
*\end{array}$ & $\begin{array}{l}0.300 \\
*\end{array}$ \\
\hline kor75 & $\begin{array}{l}0.675 \\
*\end{array}$ & $\begin{array}{l}0.806 \\
\star\end{array}$ & $\begin{array}{l}0.752 \\
*\end{array}$ & $\begin{array}{l}0.676 \\
*\end{array}$ & $\begin{array}{l}0.608 \\
*\end{array}$ & $\begin{array}{l}0.515 \\
*\end{array}$ & $\begin{array}{l}0.420 \\
*\end{array}$ \\
\hline kor80 & $\begin{array}{l}0.678 \\
*\end{array}$ & $\begin{array}{l}0.688 \\
*\end{array}$ & $\begin{array}{l}0.738 \\
*\end{array}$ & $\begin{array}{l}0.681 \\
*\end{array}$ & $\begin{array}{l}0.603 \\
*\end{array}$ & $\begin{array}{l}0.482 \\
*\end{array}$ & $\begin{array}{l}0.440 \\
*\end{array}$ \\
\hline kor85 & $\begin{array}{l}0.658 \\
*\end{array}$ & $\begin{array}{l}0.698 \\
*\end{array}$ & $\begin{array}{l}0.778 \\
*\end{array}$ & $\begin{array}{l}0.722 \\
*\end{array}$ & $\begin{array}{l}0.733 \\
*\end{array}$ & $\begin{array}{l}0.644 \\
*\end{array}$ & $\begin{array}{l}0.624 \\
*\end{array}$ \\
\hline kor90 & $\begin{array}{l}0.601 \\
*\end{array}$ & $\begin{array}{l}0.659 \\
*\end{array}$ & $\begin{array}{l}0.756 \\
*\end{array}$ & $\begin{array}{l}0.720 \\
*\end{array}$ & $\begin{array}{l}0.765 \\
*\end{array}$ & $\begin{array}{l}0.720 \\
*\end{array}$ & $\begin{array}{l}0.732 \\
*\end{array}$ \\
\hline kor95 & $\begin{array}{l}0.415 \\
*\end{array}$ & $\begin{array}{l}0.523 \\
*\end{array}$ & $\begin{array}{l}0.564 \\
*\end{array}$ & $\begin{array}{l}0.566 \\
*\end{array}$ & $\begin{array}{l}0.639 \\
*\end{array}$ & $\begin{array}{l}0.678 \\
*\end{array}$ & $\begin{array}{l}0.731 \\
\star\end{array}$ \\
\hline kor99 & $\begin{array}{l}0.289 \\
*\end{array}$ & $\begin{array}{l}0.431 \\
*\end{array}$ & $\begin{array}{l}0.524 \\
*\end{array}$ & $\begin{array}{l}0.530 \\
*\end{array}$ & $\begin{array}{l}0.592 \\
*\end{array}$ & $\begin{array}{l}0.672 \\
*\end{array}$ & $\begin{array}{l}0.730 \\
\star\end{array}$ \\
\hline
\end{tabular}

Source: calculated by author

Note: * significant at $5 \%$

** significant at $10 \%$

Table 4 Spearman's RCCs between Singapore and Korea RCA indices

\begin{tabular}{lcllllll}
\hline SGP-KOR & kor70 & kor75 & kor80 & kor85 & kor90 & kor95 & kor99 \\
\hline \hline sgp70 & $\mathbf{0 . 1 6 1}$ & 0.160 & 0.146 & 0.146 & 0.033 & -0.052 & -0.112 \\
sgp75 & 0.140 & $\begin{array}{l}\mathbf{0 . 2 4 0} \\
\star *\end{array}$ & $\begin{array}{l}0.248 \\
\star *\end{array}$ & $\begin{array}{l}0.252 \\
\star *\end{array}$ & $\begin{array}{l}0.216 \\
\star *\end{array}$ & 0.206 & 0.200 \\
sgp80 & 0.102 & 0.116 & $\mathbf{0 . 2 0 7}$ & 0.181 & 0.105 & 0.053 & 0.093 \\
sgp85 & 0.122 & 0.169 & 0.086 & $\mathbf{0 . 1 6 6}$ & 0.097 & 0.143 & 0.182 \\
sgp90 & 0.068 & 0.211 & 0.137 & 0.230 & $\mathbf{0 . 1 6 0}$ & 0.182 & 0.247 \\
sgp95 & 0.047 & 0.187 & 0.155 & 0.276 & 0.283 & $\mathbf{0 . 3 4 8}$ & 0.409 \\
sgp99 & -0.037 & 0.119 & 0.045 & 0.208 & 0.251 & 0.352 & $\mathbf{0 . 4 3 8}$
\end{tabular}




\begin{abstract}
Source: calculated by author
Note: * significant at $5 \%$

** significant at $10 \%$

ASEAN -NIEs

Thailand-NIEs

The correlation coefficients between Thailand-Korea, Hong Kong and Taiwan tend to increase in both pairs over time. Interestingly, though there exists a significant convergence between contemporaneous RCA indices of Thailand, Korea, and Taiwan, there is even a closer similarity between recent specialization pattern of Thailand and the specialization pattern of Korea in late 1980s and the specialization pattern of Taiwan from 1970-1995, and the specialization pattern of Hong Kong from 1970-1990 (comparison to the Thailand's specialization pattern in 1995 since no statistical significance for the coefficient in 1999). This implies that Thailand is following in the footsteps of Taiwan and Korea.
\end{abstract}

Table 5 Spearman's RCCs between Korea and Thailand RCA indices

\begin{tabular}{llllllll}
\hline KOR-THL & thl70 & thl75 & thl80 & thl85 & thl90 & thl95 & thl99 \\
\hline \hline kor70 & $\mathbf{0 . 1 7 5}$ & 0.368 & 0.453 & 0.354 & 0.429 & 0.393 & 0.368 \\
& & $*$ & $*$ & $*$ & $*$ & $*$ & $*$ \\
kor75 & 0.165 & $\mathbf{0 . 3 7 3}$ & 0.444 & 0.457 & 0.568 & 0.589 & 0.550 \\
& & $*$ & $*$ & $*$ & $*$ & $*$ & $*$ \\
kor80 & 0.075 & 0.265 & $\mathbf{0 . 3 9 2}$ & 0.298 & 0.441 & 0.455 & 0.391 \\
& & $*$ & $*$ & $*$ & $*$ & $*$ & $*$ \\
kor85 & 0.018 & 0.228 & 0.384 & $\mathbf{0 . 3 4 8}$ & 0.541 & 0.595 & 0.542 \\
\multirow{2}{*}{ kor90 } & & $* *$ & $*$ & $*$ & $*$ & $*$ & $*$ \\
& -0.061 & 0.153 & 0.275 & 0.276 & $\mathbf{0 . 5 2 5}$ & 0.627 & 0.567 \\
kor95 & & & $*$ & $*$ & $*$ & $*$ & $*$ \\
& -0.157 & -0.001 & 0.011 & 0.005 & 0.255 & $\mathbf{0 . 4 6 0}$ & 0.437 \\
kor99 & & & & & $*$ & $*$ & $*$ \\
& -0.182 & -0.043 & 0.008 & 0.023 & 0.254 & 0.462 & $\mathbf{0 . 4 5 9}$ \\
& & & & & $*$ & $*$ & $*$ \\
\hline
\end{tabular}

Source: calculated by author

Note: * significant at $5 \%$

** significant at $10 \%$ 
The coefficients made a relatively big increase after 1985 and tended to loose their steam in late 1990s. The increasing similarity between Thailand and NIEs after 1985 till 1995 might be explained by the yen appreciation after Plaza Accord that Japanese investors sought to move their production abroad, Thailand was on their focus at that time. The decreasing trend of similarity after 1995, on the other hand is attribute to the financial crisis out broken in late 1990s.

Table 6 Spearman's RCCs between Taiwan and Thailand RCA indices

\begin{tabular}{|c|c|c|c|c|c|c|c|}
\hline TWN-THL & thl70 & thl75 & thl80 & thl85 & thl90 & thl95 & th199 \\
\hline twn70 & 0.100 & $\begin{array}{l}0.362 \\
*\end{array}$ & $\begin{array}{l}0.390 \\
*\end{array}$ & $\begin{array}{l}0.412 \\
*\end{array}$ & $\begin{array}{l}0.553 \\
*\end{array}$ & $\begin{array}{l}0.514 \\
*\end{array}$ & $\begin{array}{l}0.501 \\
*\end{array}$ \\
\hline twn75 & -0.017 & $\begin{array}{l}0.291 \\
*\end{array}$ & $\begin{array}{l}0.345 \\
*\end{array}$ & $\begin{array}{l}0.373 \\
*\end{array}$ & $\begin{array}{l}0.586 \\
*\end{array}$ & $\begin{array}{l}0.619 \\
*\end{array}$ & $\begin{array}{l}0.566 \\
\star\end{array}$ \\
\hline twn80 & 0.000 & $\begin{array}{l}0.301 \\
*\end{array}$ & $\begin{array}{l}0.471 \\
*\end{array}$ & $\begin{array}{l}0.449 \\
*\end{array}$ & $\begin{array}{l}0.656 \\
*\end{array}$ & $\begin{array}{l}0.714 \\
*\end{array}$ & $\begin{array}{l}0.634 \\
*\end{array}$ \\
\hline twn85 & -0.074 & $\begin{array}{l}0.226 \\
\star \star\end{array}$ & $\begin{array}{l}0.444 \\
*\end{array}$ & $\begin{array}{l}0.392 \\
*\end{array}$ & $\begin{array}{l}0.618 \\
*\end{array}$ & $\begin{array}{l}0.647 \\
\text { * }\end{array}$ & $\begin{array}{l}0.563 \\
*\end{array}$ \\
\hline twn90 & -0.156 & 0.116 & $\begin{array}{l}0.296 \\
*\end{array}$ & $\begin{array}{l}0.345 \\
*\end{array}$ & $\begin{array}{l}0.591 \\
*\end{array}$ & $\begin{array}{l}0.654 \\
*\end{array}$ & $\begin{array}{l}0.589 \\
*\end{array}$ \\
\hline twn95 & -0.152 & 0.086 & $\begin{array}{l}0.218 \\
\star \star\end{array}$ & $\begin{array}{l}0.241 \\
\star *\end{array}$ & $\begin{array}{l}0.504 \\
*\end{array}$ & $\begin{array}{l}0.600 \\
*\end{array}$ & $\begin{array}{l}0.566 \\
*\end{array}$ \\
\hline twn99 & -0.109 & 0.071 & 0.161 & 0.157 & $\begin{array}{c}0.407 \\
*\end{array}$ & $\begin{array}{c}0.547 \\
*\end{array}$ & $\begin{array}{c}0.497 \\
*\end{array}$ \\
\hline
\end{tabular}

Source: calculated by author

Note: * significant at $5 \%$

** significant at $10 \%$

\section{Malaysia-NIEs}

The pair between Malaysia and Singapore has tended to be higher than that of Malaysia and Korea, Malaysia and Taiwan. The coefficients tend to rise over time implying that Malaysia is catching-up with the three. The pattern of Malaysia seems more similar with that of Singapore rather than those of Korea and Taiwan, this is because Malaysia is following a similar policy with Singapore that aims at promoting electronics industry. Interestingly, the recent specialization pattern of Malaysia is similar with that of Singapore in late 80s and early 1990s. Malaysia is becoming more competitive and less complementary with NIEs, especially with Singapore. 
Table 7 Spearman's RCCs between Singapore and Malaysia RCA indices

\begin{tabular}{llllllll}
\hline SGP-MLS & $\mathrm{mls70}$ & $\mathrm{mls75}$ & $\mathrm{mls} 80$ & $\mathrm{mls} 85$ & $\mathrm{mls} 90$ & $\mathrm{mls} 95$ & $\mathrm{mls} 99$ \\
\hline \hline sgp70 & $\mathbf{0 . 6 7 1}$ & 0.605 & 0.432 & 0.406 & 0.461 & 0.380 & 0.408 \\
& $*$ & $*$ & $*$ & $*$ & $*$ & $*$ & $*$ \\
sgp75 & 0.362 & $\mathbf{0 . 6 3 4}$ & 0.529 & 0.545 & 0.626 & 0.627 & 0.588 \\
& $*$ & $*$ & $*$ & $*$ & $*$ & $*$ & $*$ \\
sgp80 & 0.415 & 0.624 & $\mathbf{0 . 6 7 3}$ & 0.508 & 0.531 & 0.530 & 0.535 \\
& $*$ & $*$ & $*$ & $*$ & $*$ & $*$ & $*$ \\
sgp85 & 0.373 & 0.615 & 0.493 & $\mathbf{0 . 4 4 3}$ & 0.472 & 0.592 & 0.599 \\
& $*$ & $*$ & $*$ & $*$ & $*$ & $*$ & $*$ \\
sgp90 & 0.345 & 0.593 & 0.482 & 0.418 & $\mathbf{0 . 4 4 9}$ & 0.607 & 0.677 \\
& $*$ & $*$ & $*$ & $*$ & $*$ & $*$ & $*$ \\
sgp95 & 0.215 & 0.482 & 0.340 & 0.349 & 0.339 & $\mathbf{0 . 5 5 6}$ & 0.628 \\
& $*$ & $*$ & $*$ & $*$ & $*$ & $*$ & $*$ \\
sgp99 & 0.104 & 0.346 & 0.220 & 0.251 & 0.248 & 0.458 & $\mathbf{0 . 5 5 1}$ \\
& & $*$ & $*$ & $*$ & $*$ & $*$ & $*$ \\
\hline
\end{tabular}

Source: calculated by author

Note: * significant at $5 \%$

** significant at $10 \%$

What can be drawn from the analysis of the observed specialization pattern and the convergence of specialization patterns of East Asian economies?

First, the findings support the CPC model. All economies' specialization patterns seem to approximate the pattern predicted by the CPC. Japan is still leading the region with a strong comparative advantage in technology-intensive products and some capitalintensive products, followed by Korea, Taiwan whose comparative advantage has been shifted from the labor-intensive goods production toward capital-intensive and technologyintensive goods production. Singapore is a bit behind Korea and Taiwan, since it has decided to skip over developing capital-intensive goods production, from labor-intensive goods production to technology-intensive goods production. Following next are the four members of ASEAN including Indonesia, Malaysia, the Philippines, and Thailand. Indonesia is still producing the labor-intensive products while improving the competitiveness of capital-intensive goods production, the Philippines has a strong comparative advantage in labor-intensive products, but no improvement has been seen in the capital-intensive products, technology-intensive products' competitiveness has been improved by the inflow surge of Japanese FDI. Thailand and Malaysia seem to have followed in the footsteps of Singapore in which they skipped over the capital-intensive 
goods production and moved directly to technology-intensive goods production. The skipping over has been assisted by the surge of Japanese FDI after the Plaza Accord that caused Yen appreciation. The exception of Thailand and Malaysia are not in contrast with the prediction of CPC since the model implies that the government intervention might accelerate or impede the shifting of industries.

Second, the CPC model predicts the relocation of industries from one country to another because of the shift in comparative advantages. There is a hierarchical structure with Japan as the leading innovative country that has transferred industries to other countries in the region according to their level of development. Some evidence in favor of this prediction is also found if we look at the Spearman's rank correlation coefficients between Japan in 1970-Korea, and Taiwan at present; and NIEs from 70-1990 and ASEAN at present. The Spearman's rank correlation coefficients are larger than those of the contemporaneous correlation coefficients reported for pairs at present.

\section{Application to Vietnam}

East Asia has experienced a very unique development pattern where there has existed an economic development linkage among economies. One by one, countries in different development levels have achieved economic growth by continuously upgrading the industrial structures. Trade and investment linkage, a hierarchical order of industrial structures has been uniquely observed in the region. Thanks to the linkage, the modern industries have been geographically widening from the early industrializing to the lateindustrializing country creating the international division of labor, and network production on the one hand and structural deepening within each country on the other.

For the late-industrializing country, it is very important to be one crucial link in this production network under competitive pressure from and complementary with neighboring countries. Through the linkage, industrial upgrading is possibly realized from natural resource based economy to low-tech based economy (labor-intensive, capital-intensive based economy) to hi-tech based economy. To this end, the late-industrializing country has no choice but to undertake international integration via trade and investment.

Located in the center of East Asia, under the globalization, Vietnam, a lateindustrializing country, is in a transition from a centrally planned to a market economy. Vietnam is striving for the goal of industrialization and modernization - a goal widely shared by other developing and transitional countries. The globalization and the opening of economy have been exposing the country to international environment via trade and investment interaction leading to establishing development linkage among economies. Though Vietnam has a good potential to join the Asian dynamism, Vietnam is still not prepared to take full advantage of development linkage for economic integration.

The fact that international integration comes with both challenges and opportunities is well understood. The opening of economy is the right direction in the long run, but in the 
short run, there will be so many difficulties in adjustment that Vietnam has to face during the catching-up with more advanced economies. One of them is that the liberalization without strategy might cause the collapse of industries with potential comparative advantage. Various measures such as industrial promotion, FDI and trade policy are not well defined to take advantage of the economic development linkage as well as to prevent the collapse of industries.

This part will identify the gap as well as the similarity between Vietnam and ASEAN 4 in trade and investment so as to visualize the linkage for Vietnam. Based on the linkage, the potential comparative advantage will be traced out for the foundations of Vietnam's trade and industrial policies.

\subsection{Comparison between Vietnam and ASEAN 4:}

\subsubsection{Macroeconomic performance}

Vietnam is a late-industrializing economy. The economy has been transiting the economy from the centrally planned economy to a market economy since 1986 . Her population is the second largest among ASEAN members. However, Vietnam, at present still remains at a low stage of development in the region since there is a big difference in GDP, Vietnam's GDP in 2000 is about USD 31 billion while the Philippines has the lowest GDP among ASEAN 4 of USD 75 billion. Vietnam's per capital income is about a half of Indonesia's per capita income.

Vietnam's growth rates of 8\% over the period of 1991-1995 were as high as ASEAN members, and the growth rates have been maintained higher than ASEAN in the late 1990s in spite of the outbreak of the financial crisis, 7\% in Vietnam compared with the $5 \%$ growth rate of Malaysia. Moreover, the inflation rate has been brought into control and converged to a moderate rate of $4 \%$ in the late 1990s. Where does the strength of Vietnam's macro economy come from? It is not because Vietnam is already competitive in the global economy. The main reason can be found in the external balance with the transfer of over USD 6300 million and the large inflow of FDI (USD 700 million), tourism receipts (USD1,500 million) which accounts for about 30\% of GDP. Thus, even though Vietnam recently achieved such high growth rates; there is no guarantee that Vietnam will be able to sustain high growth in the future, unless Vietnam improves its competitiveness quickly as the international integration proceeds.

\subsubsection{Factor endowment: does Vietnam take full use of its available factors?}

In order to determine whether Vietnam has taken full use of its comparative advantage and to identify the dynamic comparative advantage, the comparison of Vietnam's factor endowment with other ASEAN four is needed. The factors to be analyzed include land, capital, and labor. The capital is considered in the contents of domestic capital stocks to see the capital availability of Vietnam itself. FDI will be analyzed in the later part. 
Capital endowments are divided into human and physical capital. The calculation of national capital stocks is made by summing a country's Gross Domestic Investment flows over time while applying deflation and depreciation factors. GDI flows measure expenditure for the addition of reproducible capital goods by the private and public sector. Excluded are increases in natural resources and government expenditures for construction and durable goods for military purposes. There is considerable latitude in choosing a rate of depreciation. Leamer (1974) considered three different asset lives: 10, 15, and 20 years. The life of 15 years was selected. By considering the double declining balance method, Leamer applied $13.3 \%$ as the rate of depreciation.

$\mathrm{I}_{\mathrm{t}}=$ gross domestic investment in year $\mathrm{t}$ in units of home currency

$\mathrm{P}_{t}^{b}=$ implicit gross domestic investment deflator at time $\mathrm{t}$ with base year $\mathrm{b}, \mathrm{P}_{b}^{b}=0$

$e_{t}=$ exchange rate in time period $t$, home currency per dollar

$\delta=$ rate of depreciation

The real capital stock at the end of year $t$ in year b home currency is:

$$
\mathrm{K}_{t}^{b}=\sum_{j=0}^{t}(1-\delta)^{t-j}\left(\mathrm{I}_{\mathrm{j}} / \mathrm{P}_{\mathrm{j}}^{\mathrm{b}}\right)
$$

Multiplying this year t capital stock by the year t GDI deflator in domestic currency units and divide by the exchange rate in year t gives the current dollar value capital stock

$$
\mathrm{K}_{t}^{\$}=\frac{\mathrm{K}_{\mathrm{t}}^{\mathrm{b}} \mathrm{P}_{\mathrm{t}}^{\mathrm{b}}}{\mathrm{e}_{\mathrm{t}}}
$$

To estimate the endowments of human capital, I will use the number of people enrolled in secondary school as a percentage of age group compiled by WB.

The endowments of labor can be analyzed by seeing the ratio of unskilled labor and skilled labor. The unskilled labor ratio is the ratio of agriculture, animal husbandry and forestry workers, fisherman and hunters and production and related workers, transport equipment operators and laborers to total economically active population.

Vietnam endowed with unskilled labor but not much capital including human and physical capital. More than 70 percent of her labor force is unskilled. Though Vietnam is not endowed with much physical capital, Vietnam, Indonesia and Thailand have similarities in the unskilled labor ratio and human capital. If the specialization pattern of Vietnam corresponds to the CPC, the country will potentially have a comparative advantage in commodities in which Thailand, and Indonesia have a comparative advantage . 


\begin{tabular}{|c|c|c|c|c|}
\hline Country & Capital & & Land 1996 & Unskilled labor Ratio (\%) \\
\hline & (1) & $(2)$ & & \\
\hline IDN & 116.60 & 57 & 0.09 & 70 \\
\hline MLS & 121.7678 & 70 & 0.08 & 55 \\
\hline THL & 196.77 & 82 & 0.28 & 65 \\
\hline C & na & 19 & 0.39 & na \\
\hline $\mathrm{L}$ & na & 38 & 0.19 & na \\
\hline M & 115.48 & 39 & 0.21 & na \\
\hline $\mathrm{V}$ & 26.32 & 67 & 0.07 & 71 \\
\hline
\end{tabular}

Source: Calculation based on WB (World Development Indicators, 2000), IFS

Note:

(1): Physical capital accumulated from 1990-1999 in US\$ billions

(2) Human capital - Gross Enrollment Ratio of Secondary School (2001)

Land: Arable Land 1996, Hectares per capita

Unskilled Labor: The ratio of agriculture, forestry, fishing workers,

personally-serviced laborers to total active population

Unskilled Labor of Vietnam: 1998, other countries: 1994, 1995

\subsubsection{Trade and investment interaction between Vietnam and the world.}

The opening of one economy is determined by the export and import per GDP. Vietnam's openness has been increasing since its Doimoi policy. Vietnam's export over GDP, and import over GDP was recorded at 46\% and 48\% in 2000 respectively. Her openness is similar to that of the Philippines, and Thailand.

Another factor should be put into consideration when analyzing the comparative advantage of one country. This is the exchange rate regime. Vietnam has been implementing the managed floating system. Vietnamese currency has been stabilized, while other currencies of other late-industrializing countries such as Cambodia, Laos have been depreciating. The Riel depreciated by $80 \%$ in 1992-1993, Kip continues to depreciate. Vietnam's competitiveness weakened.

Vietnam joined ASEAN in 1995, and AFTA one year later. The trade liberalization in AFTA brings the hope for Vietnam to have deeper trade and investment interaction. Yet, Vietnam's export to ASEAN has been almost unchanged, 16\% of its export incomes earned from ASEAN in 1995, but in 2000 this proportion slightly decreased to 15.6\%. The reason behind this is that Vietnam has not set up the linkage with the region so that her products are not competitive enough to enter the ASEAN members' market, that is, Vietnam has still 
been investing much in the capital-intensive industries meanwhile she has untapped comparative advantage in labor-intensive products. This will be further explained in the following.

Large portion of Vietnam's FDI, 19 percent comes from ASEAN, the smallest portion in comparison with Cambodia, Myanmar, and Laos, 33\%, 70\%, 82\% respectively. It is worth noticing that FDI is capital-intensive. The FDI in production of capital-intensive goods accounted for a majority of investment in the manufacturing industries: 26\%, meanwhile labor-intensive industries absorbed only 5\%. The export-oriented and laborintensive foreign investment, which is attracted by Vietnam's high human capital and low labor costs, is still modest.

Although FDI accounted for 31.8\% of industrial production in 1998, and accounted for almost half of industrial growth over the period 1995-1998, it employed only $11.5 \%$ of all industrial workers. Why does the FDI go to capital-intensive industries? The reason behind is the protection that the government is providing for the sector in which the SOEs are dominant. FDI established joint ventures with those SOEs to enjoy the importsubstitution.

\subsection{Vietnam: catching-up.}

\subsubsection{Catching-up: RCA curves and pattern of industrial development:}

The Vietnam's RCA curves took the shape of a less developed economy with the high value of RCA indices in natural-intensive products, and labor-intensive products. Although the number of natural resource intensive products showing a strong comparative advantage over 1991-1999 is still rather dominating. The laborintensive products began to appear in the top 20 of Vietnam's RCA,

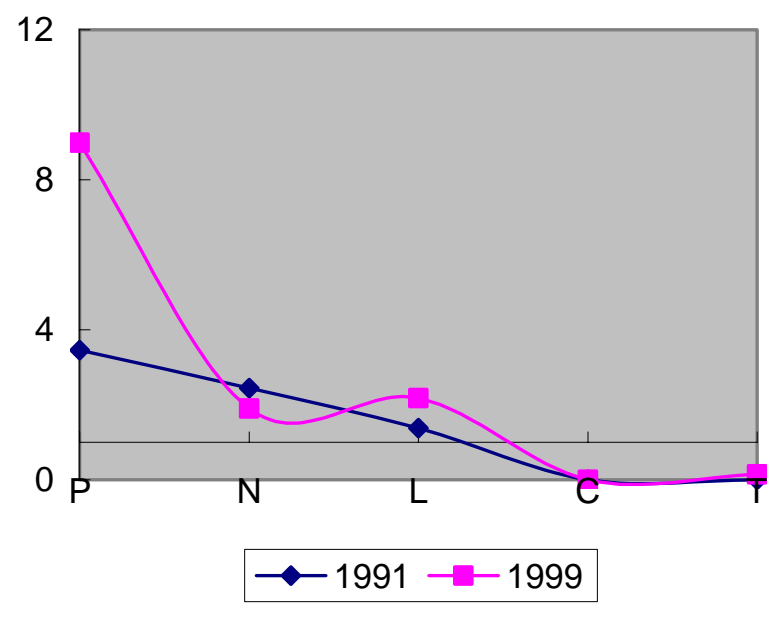

Figure 6 Vietnam's RCA curves

Source: author Vietnam's low labor costs provide an incentive to expand the assembly and manufacture of a wide range of labor-intensive consumer goods, which the NIEs in the region are gradually ceasing to produce due to increasing labor costs. The FDI policy has also made a great contribution to the existence of some components of the labor-intensive industries such as garment and footwear in Vietnam, where capital is scarcely endowed. It is worth noting two components, articles of apparel and clothing accessories (SITC84) and footwear (SITC85), which together account for nearly 25\% of Vietnam's total exports. SITC 84 has become the second most important source of Vietnam's exports; meanwhile SITC 85 has become the fourth important of 
Vietnam's exports. The more than one-comparative advantage index in the labor-intensive aggregate can be explained by Vietnam's relative abundance in unskilled labor. The emergence of labor-intensive industries due to the changes in trade policies that private companies and FDI enterprises were allowed in international trade. This performance in labor-intensive sector has been mostly supported by FDI (textile and footwear).

The capital-intensive products were still mostly imported. The expanding laborintensive industries require intermediate inputs such as textile yarn, fabrics, and made-up parts, related products (SITC65). Therefore, textile industry (SITC 65) is the only one in capital-intensive sector in which Vietnam has a comparative advantage. Hence, although absorbing a big portion of FDI as well as the investment from the government, this sector is still uncompetitive. The reasons for this will be discussed in the latter part.

Regarding to the technology-intensive sector, Vietnam imports were mainly technology-intensive products due to insufficient or non-existent domestic production, or weak competition. The components with the largest share in total 1999 imports were electrical machinery, apparatus and appliances (SITC 77), machinery specialized for particular industries (SITC72), road vehicles (SITC 78). The strongly negative value of RCA index for technology-intensive products indicated an unrealized comparative advantage.

\subsubsection{Players in the industrial development}

The state and domestic non-state sectors have grown rapidly over the period of 1995-1998. In terms of size, however, the state sector still dominates the economy. In 1998, its contribution to industrial value-added was more than twice as large as that of the domestic private sector. Accordingly, a large share of recent industrial expansion relies on the role of state enterprises. Between 1995 and 1998, state companies had accounted for $37.2 \%$ of Vietnam's total industrial growth, compared to $16.2 \%$ for domestic private companies.

Though state sector contributed a big bulk in the industrial growth, it is less laborintensive than the domestic non-state enterprises. In 1997/1998 it provided jobs for less than $25 \%$ of industrial workers. This contrasted with the non-domestic non-state sector, which, despite its smaller size, employed more than $64 \%$ of industrial workers.

The state enterprises, which are still concentrated in import-substituting production, are not competitive. The RCA index of capital-intensive aggregation, valued at almost zero in 1999 reflects the weak competitiveness. This is an inefficient use of capital, and other resources from the private sector.

Meanwhile, the private sector is mostly labor-intensive, mainly in textiles, garments or in primary processing, taking the country's comparative advantage. Accordingly, they are more export-oriented than the state enterprises. They export on average around three 
quarters of their production. This contrasts sharply with state enterprises, where only about $12 \%$ of production is exported. Thus, while the capital-intensive state sector is mainly inward -looking, export markets are clearly the main engines of private sector growth.

\subsubsection{Statistical Tests of Export Similarity and Convergence}

To test the dynamic change within Vietnam and the catch-up of Vietnam with other advanced economies, the Spearman's rank correlation coefficients are calculated for each pair Vietnam-Japan, Vietnam-NIEs, Vietnam-ASEAN members, and Vietnam-Vietnam.

The RCA index reveals that Vietnam's current comparative advantage mainly relies on natural-resource-intensive and labor-intensive products such as cereals, coffee, fishery, rubber, cork and wood, coal, crude oil, travel goods, textiles, garments and footwear. Meanwhile, Japan has an advanced structure consisting of technology-intensive products. The ranking must be different. Indeed, the coefficients are all negative implying that the rankings of Vietnam are far different from those of Japan. Vietnam and Japan are complementary rather than competitive.

Table 9 Spearman's RCCs between JPN \&V

\begin{tabular}{llll}
\hline JPN-V & v91 & v95 & v99 \\
\hline jpn70 & -0.189 & -0.195 & -0.151 \\
& & & \\
jpn75 & -0.264 & -0.308 & -0.287 \\
& $*$ & $*$ & $*$ \\
jpn80 & -0.305 & -0.309 & -0.244 \\
& $*$ & $*$ & $* *$ \\
jpn85 & -0.370 & -0.359 & -0.265 \\
& $*$ & $*$ & $*$ \\
jpn90 & $\mathbf{- 0 . 4 2 2}$ & -0.394 & -0.269 \\
& $*$ & $*$ & $*$ \\
jpn95 & -0.298 & $\mathbf{- 0 . 2 6 0}$ & -0.255 \\
& $*$ & $*$ & $*$ \\
jpn99 & -0.282 & -0.268 & $\mathbf{- 0 . 2 8 6}$ \\
& $*$ & $*$ & $*$ \\
\hline
\end{tabular}

Source: author

Note: * significant at $5 \%$

** significant at $10 \%$
Table 10 Spearman's RCCs between THL\&V

\begin{tabular}{rccc}
\hline THL-V & $\mathrm{v} 91$ & $\mathrm{v} 95$ & $\mathrm{v} 99$ \\
\hline thl70 & $\begin{array}{l}0.297 \\
*\end{array}$ & $\begin{array}{c}0.222 \\
* *\end{array}$ & 0.099 \\
thl75 & $\begin{array}{l}0.274 \\
*\end{array}$ & $\begin{array}{c}0.242 \\
* *\end{array}$ & 0.187 \\
thl80 & 0.204 & 0.181 & $\begin{array}{l}0.212 \\
* *\end{array}$ \\
thl85 & 0.138 & 0.178 & $\begin{array}{l}0.277 \\
*\end{array}$ \\
thl90 & $\mathbf{0 . 0 2 2}$ & 0.085 & $\begin{array}{l}0.285 \\
\text { (n) }\end{array}$ \\
thl95 & 0.050 & $\mathbf{0 . 1 1 6}$ & $\begin{array}{l}0.250 \\
*\end{array}$ \\
thl99 & 0.078 & 0.174 & $\mathbf{0 . 3 0 8}$ \\
& & & $*$ \\
\hline
\end{tabular}

Source: author

Note: * significant at $5 \%$

** significant at $10 \%$

The pair of Vietnam-Thailand shows that a few coefficients have statistical significance. The coefficients indicate that Vietnam may compete with Thailand for certain labor-intensive products and natural-resource-intensive products. On the other hand, 
Vietnam and Thailand are complementary if the technology-intensive products are taken into consideration.

Vietnam has made a slight change in the industrial structure. Over the sub-periods of 1990-1995 and 1995-1999, the ranked RCA structure has not made a drastic change, they seem to have stabilized as the coefficients are 0.845 and 0.812 respectively. Yet, if we compare the period 1999-1990, we found that a relatively impressive change has been made, the coefficient is 0.607 . However, the change has been made at a slow pace.

\subsubsection{Potential comparative advantage}

The above analysis is based on the RCA index. However, in order to predict one country's future industrial structure, potential comparative advantage needs to be examined.

The potential comparative advantage can be determined by factor endowments and by referring to early-industrializing economies. If two countries have similar factor endowments, but one industrialized earlier, the other is likely to have specialization pattern that is more or less similar to that of the early industrializing economy. The size of economy also affects the comparative advantage in the sense that although small economy has a comparative advantage in one manufacture aggregation, it does not imply that it has a comparative advantage in all commodities in that aggregation. If one country is large in terms of the size, then it might make rapid improvements in the comparative advantage in a wide spectrum of products, while the small country improves some industries but not all. China is a good example that she has a comparative advantage in a wide spectrum of manufactured products ${ }^{2}$.

The similarity index is affected by the size limit. Thus, Spearman's rank correlation coefficients between Vietnam and other countries in the region are small, but the analysis of ranked RCA and the Spearman's rank correlation coefficient reveal that Vietnam has started flying with other economies in the region, becoming one member in the flock of CPC.

However, her flying speed is still very slow. The reason is the inefficient structure of investment. Much investment has been made in the capital-intensive goods production, but the industry shows comparative disadvantage. In contrast to that, though the laborintensive sector absorbed quite a modest amount of capital, the sector earned quite an impressive bulk of foreign exchange for the country, and showed quite a strong comparative advantage.

However, the labor-sector has been untapped yet, since its contribution to the country growth was still modest, only $22 \%$ in comparison with the contribution of capital, $54 \%$. Moreover, though export growth of labor-intensive products and capital-intensive

\footnotetext{
${ }^{2}$ METI white paper, 2002
} 
products were almost identical, the export shares of labor-intensive products were 6 times as much as that of capital-intensive products.

Though Vietnam, Indonesia, and Thailand share similarities in factor endowment, Vietnam was left behind. Vietnam should have had a more modern industrial structure (see appendix 1) if she set up the linkage between her and other more advanced economies in the region. The linkage can be set up by tracing out the dynamic comparative advantage for herself so as to build up the industrial structure that joins the production network in the region.

The analysis in the first part has shown that a country's specialization structure are determined by the development stage of that country. In particular, the structure is determined by the availability of the capital resources, both human and physical capital. This confirms the predictions of the CPC model, according to which the specialization pattern in a open economy will gradually move from simple production to more sophisticated production, from natural-resource intensive to labor-intensive, capitalintensive, and technology-intensive goods production. And the country at the same level of development with the other, but late industrializing should follow in the footsteps of the early-industrializing ones. Therefore, there exists anarchy in the region lead by Japan, followed by NIEs, and ASEAN, Vietnam, Cambodia, Laos, and Myanmar. This gives two important implications: the later-industrializing can learn how to develop its own industrial structure from the early-industrializing countries, second, if good cooperation is set up, there will be a production network (international division of labor) in the region.

Though there has been a shift toward the labor-intensive, Vietnam's industrial structure is still biased in favor of capital-intensive goods production. Vietnam has not taken up all her comparative advantage yet. On the other hand, the capital-intensive goods production is strongly protected, but does not show any comparative advantage. It is undeniable that Vietnam should lay the foundation for the capital-intensive goods production, but what Vietnam is doing now is to protect the state owned enterprises, indirectly protect the import-substituting industries. Vietnam should have a strategy to protect the promising export industries instead of the state owned enterprises. The promising industries can be determined based on the dynamic comparative advantage and the CPC model.

Vietnam, Thailand, and Indonesia have the similar factor endowments. Thailand and Indonesia's industrial development can be used to trace out the promising industries for Vietnam. Vietnam's potential comparative advantage will tend to shift toward the products in which Thailand and Indonesia currently have a comparative advantage. The appendix 1 provides the RCA values of Vietnam, Thailand, and Indonesia. The underlined numbers with more than 1 value show the potential comparative advantage of Vietnam. They include furniture (SITC 82), miscellaneous manufactured articles (SITC 89), non-metallic mineral manufacture (SITC 66), capital intensive products - plastic (SITC 57), leather manufacture (SITC 61), rubber manufactures (SITC62), and some technology-intensive: office machines 
and automatic data processing equipment (SITC 75), electrical machinery, apparatus and appliances (SITC77), and telecommunication and sound recording apparatus (SITC76).

Import-substitution is necessary, but the government needs to be careful what industries should be protected since wrong selection could lead to inefficient industrial structure, and inefficient use of resources. At present, high barriers to capital-intensive imports, which not only protect SOEs but also attract foreign investors into importsubstituting and capital-intensive activities, often in joint ventures with SOEs. Vietnam's tight quota on automobiles (SITC78) is a good example. Vietnam has not gained any comparative advantage for this industry, since all car producers try to set up joint ventures with Vietnam state owned enterprises to hide from foreign competition without reducing costs.

\section{Government Intervention and industrial development}

The success of East Asia cannot have been achieved without the government intervention. The intervention is also accepted in the CPC model. However, in fact, the government intervention may never work well to promote the industrial development, sometimes wrong intervention may impede the industrial development. The government intervention, which is often through trade and industrial policies, should be solely aimed at the potential comparative advantage, which helps one economy to upgrade her industrial structure. The next chapter will focus on evaluating Vietnam's trade and industrial polices.

\subsection{Before Doi moi from 1976-1986}

After its reunification in 1975, industrialization was implemented all across country. This industrialization had many features of a typical planned economy model.

First, central-planned economies believed in rapid industrialization based on largescale technology. A capital-intensive industrial base, specifically, the heavy industry was built up with external support, mainly from the Soviet Union. This is a very unique industrialization policy. Most countries industrialized by developing the labor-intensive industry at their early stage of development, by promoting labor-intensive industries; they accumulate both human capital and physical capital for heavy industry in the next step. Japan would be a good example, in 1854, Japan opened its economy, and started its industrialization by focusing on light industry, which requires less capital, but much labor, for more than 50 years before it focused on its heavy industry, which requires much capital.

Second, the planned economy does not allow the private sector, all enterprises were either owned by the central or provincial government. The government allocated capital and production inputs to manage the economy. Even labor was allocated centrally for the modern sector. All key prices, including wages and the interest rate on capital were determined by the government. The goals of enterprises were set in terms of quantitative production targets. The state supplied them with cheap production inputs and capital. Although capital was scarce, interest rates were maintained low or even negative in real 
terms. The state owned enterprises were not punished for inefficiency and unprofitability as long as the quantitative targets had been achieved.

Third, in the central-planned economy, a large part of foreign trade was based on barter agreements with other members of the Council for Mutual Economic Assistance (CMEA). All trade terms, prices were determined by agreement. Foreign currency was strictly rationed and many parallel exchange rates prevailed for different purposes. Goods were traded through foreign trade organizations at administered domestic prices. Thus, although tariffs were generally low, exchange controls, other price based measures, and central-planed procedures provided a high level of protection for the domestic production. There was hardly real trade interaction that might have put the economy in line with her comparative advantage.

This irrational policy of industrialization caused lower industrial growth and an inefficiently structured economy. It is the fact that more than $80 \%$ of Vietnam's population were farmers, the labor force was unskilled, and it is, thus, impossible to industrialize the economy by developing heavy industry. Developing heavy industry also requires more capital while it needs a longer time to get capital return, this makes it unfeasible for Vietnam, a country where capital is scarce. On the other hand, if Vietnam had developed the light industries and consumer goods, the population structure would have been a big market to absorb the outputs; the time to have capital return would have been much shorter, the capital then could have been put more effectively into production.

The ultimate objective of this strategy was to achieve a high degree of selfsufficiency by relying to a great extent on domestic production and to finance necessary imports by exporting the surplus production. Thus, capital-intensive industries developed in Vietnam were not based on the factor endowments of the country. Instead of deriving advantage from abundant factors of production, the industrial sector absorbed scarce resources and increased dependency on external aid and in the form of materials and capital. The consequence was that agriculture and labor-intensive industries, which should have been built up first, were discriminated. Due to insufficient investment, lack of food supplies and consumer goods was a daily phenomenon in Vietnam at that time.

The heavy industry gave policy-makers a negative picture of industrialization as a result of the above industrial policies. Instead of deriving advantage from abundant factors of production, the heavy industry, which received the most investment, absorbing a large amount of capital, was very inefficient. Investment made to this industry increased by 59\%, but the growth was only $2.5 \%$ within 5 years (1976-1980).

The shortage of consumer goods and food in the previous phase changed the government's attitude toward the heavy industry. The government's industrialization policy changed its priority to the consumer goods and food industry. As a result, Vietnam's economy recorded a notable growth rate in industries. The annual average industry growth rate was $9.5 \%$. 
Another progress that is worth noting is: the government's recognition of the importance of the private sector and foreign direct investment for its industrialization. However, in 1985 the government carried out 'price, wage and money' reform, including: (1) wage adjustment and abolition of subsidized supplies of consumer necessities, (2) abolition of the system of subsidizing agricultural products, and liberalization and unification of prices, and (3) introduction of new currency with new denominations which did not work and the result was namely higher prices. Hyperinflation surged as a result of the expanded money supply, the bottleneck in production, and people's expectation. All these factors caused hyperinflation in 1985 (300\%), and the hyperinflation continued until 1986 when it reached the peak of $774.7 \%$. In short, at the end of this period, the economy was put into crisis.

As a result of the government intervention, industries developed in Vietnam were not based on the comparative advantage. Heavy industry absorbed 59\% of capital but achieved a growth of only $2.5 \%$ over 1976-1980. Insufficient investment was made in light industries. In the late 1970s, because of reduced foreign aid, shortage of food, consumer products and industrial inputs, some experimental reforms were introduced: enterprises were allowed to do business with each other if they had fulfilled their obligations. The production can be diversified in accordance with the market. And in 1986, after the peak of the crisis, the country initiated Doimoi policy.

\subsection{Policies after Doimoi.}

That economic crisis made Vietnam face the question 'life or death'. In such a circumstance, the five-year Plan (1986-1990) was designed to carry out overall economic reform called 'Doimoi'.

Doimoi policy consists of the following four points: (1) socialism cannot be achieved in a short time. Thus the capitalist factors are necessary for the industrialization. (2) It is necessary to shift priority from heavy industry to foods, consumer goods and export goods. (3) Capitalist management is to be allowed. (4) Vietnam should find its place in the division of labor, and international economic cooperation. This is, actually an attempt to set up the linkage between Vietnam and the other economies.

The Doimoi policy overall describes what the industrialization strategy would be like. Mobilizing all resources including private sector and direct investment, shifting priority from heavy industry to foods and consumer goods with consideration of international division of labor and international economic cooperation are described as the industrialization policy. Shifting priority toward labor-intensive via 3 stages:

o Investment in heavy industry decreased,

o Large investment to three economic programs: food program, consumer goods program, export goods program. 
o Priority to products with potential exports and some importsubstitution items: misleading.

In fact, the implementation still tends to take the tracks of the policies in the period before Doimoi. Though the government repeatedly stated that the investment in heavy industry would be reduced, the government still provided import-substitution policy to protect the capital-intensive state owned enterprises from the collapse. Indirectly, investment in this sector was not under control, but it tended to increase, since the foreign investors felt assured that they can enjoyed the policy as long as they just set up joint ventures with SOEs. Most SOEs are capital-intensive: steel, motorcycle, and industrial equipments. Import-substitution applied to these industries. Thus, FDI inflow is marketseeking FDI rather then labor seeking. The big proportion of FDI inflow (56\%) that is under the form of joint venture reflects this trend.

Attraction of FDI is the right policy for the country with scarce capital, but FDI must be used efficiently for the sake of upgrading industrial structure. However, Vietnam's industrial policies mislead FDI inflow to become market seeking FDI rather than exportoriented FDI. Another issue has come up is that industrial structure must be supported by parts and components industries. To achieve this, the government needs to create incentives for the supporting industries to locate and develop. However, in Vietnam, the government, instead of creating incentives for part suppliers to locate, it has been concentrating on forcing FDI enterprises to obey by localization policy. As a matter of course, this policy has shown failure because the economic environment is not good enough for the parts and components suppliers to come and set up their factories in Vietnam. The example of automobile industries is a good example.

Though remarkable achievements have been recorded, the way to industrialize has not been well defined. Even in the recent five-year Plan (1996-2000), the government only pointed out that this period would create the foundation for Vietnam to step into the 21st century and become an industrialized country in 2020. How we can proceed has not been yet mentioned. In addition, no measures have been defined to promote Vietnam's industries when Vietnam fully implements obligations of ASEAN Free Trade Area (AFTA) ${ }^{3}$ as well as those of World Trade Organization (WTO) ${ }^{4}$. As Vietnam committed to the obligations of AFTA, trade policy should be the tools to promote the promising industries that based on the country's potential comparative advantage.

\subsubsection{Trade Policies}

Over more than the past ten years, there has been significant liberalization of foreign trade regime in Vietnam. One of the big changes is that all firms and enterprises have automatic trading rights. Export promotion measures have been taken such as

\footnotetext{
${ }^{3}$ Vietnam became a member of Association of Southeast Asia Nations in 1995, and committed to obligations of AFTA in 1996

${ }^{4}$ Vietnam has logged in its application for WTO’s membership in 1994
} 
allowing private rice exports, the auctioning of garments export quotas, the provision of financial incentives to exporters, the removal of restrictions on foreign invested enterprises to export, the elimination of many export taxes, etc. Trade reforms help the private sector to get access to imported inputs and to export outlets. Liberalized trade, as well as easier domestic and foreign private entry, would increase the trade interaction so that the resource allocation will be made in efficient manner. Obviously trade reform not only increases the competition, but also raises the returns to exports, and encourages investors to move into new modern industries that are in line with the country's comparative advantage.

Vietnam started the trade reform in late 1980s after the Doi moi was initiated. In 1988, a breakthrough has been made to abolish the government monopoly on trade, the custom tariff was for the first time introduced and the private sector was officially recognized. Further trade reforms has proceeded by removing quotas on all except for certain export and import commodities, the coverage and the rates of export duties were reduced considerably, the foreign exchange system was unified, and producers were allowed to sell to any licensed foreign trade company.

The reform was rapidly made during the early 1990s. Private firms were allowed to participate in foreign trade; tariff exemptions were introduced for inputs used in the production of exports; the no tariff barriers was reduced. During 1991 - 1997, just before the financial crises, the average rate of export growth was particularly high at $28 \%$. During the late 1990s, progress was made in a number of areas, including reductions in maximum import tariff rates, the implementation of tariff reductions associated with membership of the AFTA.

The Vietnam's trade policy can be described as a mixture of import-substitution and export promotion. There is no need to discuss the importance of applying importsubstitution in the earlier stage of development, since there are a remarkable number of literatures studying this. Vietnam has her own objective of turning the country into an industrialized country by 2020. Import-substitution is necessary. Considerable attention has been paid to the development of the industrial base through a combination of export orientation and import substitution. Vietnam tends to protect agricultural, some of laborintensive products such as textiles, garments, furniture, some technology-intensive products such as automobile. The maximum tariff on alcohol, petroleum products, automobiles, motorbikes, cosmetics, glass, and glass products. Low or minimum tariff rates on material inputs, machinery, equipment, especially those are presently not manufactured by Vietnam. The trade policy still leaves holes for the foreign competition against the promising industries. Or in other words, there exists no linkage between potential comparative advantage and trade policy.

In preparing a strategy to deal with the economic integration, the government has two tasks to solve aiming at improving competitiveness of existing industries, and the potential industries. The government has to identify the industries in which it has a comparative advantage and industries in which it will potentially have a comparative 
advantage. The policy concerns, which are toward these tasks, are different. The main concern of the first is about reducing costs of protection and facilitating the improvement of competitiveness, while the concern of the second task is to promote the potential industries by applying certain protection.

However, in fact, what Vietnam is doing is very different. The table 11 shows Vietnam's current comparative advantage and potential comparative advantage. The current comparative advantage and potential comparative advantage are shown by the SITC codes of products in the third row. SITC codes, which are listed in this figure, are determined in section 5. The codes, which are regularly written, represent the products in which Vietnam currently has comparative advantage, and the codes, which are underlined, represent the products in which Vietnam will potentially have comparative advantage. The fifth row shows the effective rate of protection that Vietnam is applying for those products. The effective rate protection given to the manufactures having comparative advantage such as SITC 83, 84, 85, 65 is relatively high, while low rate of protection is given to the potential industries such as SITC 61, 62, , 75, 76, 77. Vietnam tends to maintain high protection for the products that it has already had comparative advantage. On the other hand, the products that need such a protection are not heavily protected. This implies that Vietnam has not set up a strategy for economic integration yet.

Table11 Protection for Potential Industries?

\begin{tabular}{|c|c|c|c|}
\hline $\mathbf{P}-\mathbf{N}$ & $\mathbf{L}$ & $\mathbf{C}$ & $\mathbf{T}$ \\
\hline \multicolumn{4}{|c|}{ Actual comparative advantage and potential comparative advantage (SITC codes)* } \\
\hline $33,32,63,5,7,23,3,29,4,22$ & $\underline{66}, \underline{82}, 83,84,85, \underline{89}$ & $\underline{56}, \underline{57}, \underline{61}, \underline{62}, 65$ & $\underline{75}, \underline{76}, \underline{77,} \underline{88}$ \\
\hline \multicolumn{4}{|c|}{ Effective rate of protection $(\%)$} \\
\hline $\begin{array}{c}\text { na, }-14,4,15.2,41.6,59.6 \text {, na } \\
66.6,0.9,-4.6,1.4\end{array}$ & $\underline{\text { na, }} \underset{\text { 64.3 }}{6} \underset{\text { na }}{64.3,229.8,229.8,}$ & $\frac{6.3,}{-15.1}, \underline{-0.1}$ & $-0.6, \underline{13.8}, \underline{13.8}$ \\
\hline
\end{tabular}

Source: author, and effective rate of production is reproduced from Center for International Economics

Note: - *: regularly-written SITC codes are the products, in which Vietnam currently has comparative advantage, and underlined SITC codes are the products in which Vietnam will potentially have comparative advantage

- na: not available

\section{Conclusion}

In this paper, I attempt to examine the catching up process in industrial development of East Asian economies paying particular attention to the implications of the evolving specialization patterns for the late-industrializing economies such as Vietnam: has Vietnam joined the regional dynamism? How can Vietnam industrialize and catch up with the earlyindustrializing economies in the region?. While analyzing the evolution of comparative 
advantage in East Asia over the period of 1970-1999, I calculate RCA indices for Japan, NIEs, ASEAN 4, and Vietnam, and detect their industrial development through RCA curve and Spearman's rank correlation coefficient.

In particular, I find that the industrial development of regional economies supports the CPC model. All economies' evolving specialization patterns approximates the prediction of the model. Japan is still leading the region with a strong comparative advantage in technology-intensive products, and some capital-intensive products, followed by NIEs - Korea, Taiwan, Singapore, and Hong Kong who have a comparative advantage in capital-intensive products, and technology-intensive products. Yet, in the NIEs, due to the intervention by the government, Hong Kong seems to turn it into a financial hub rather than continuing to catch up with others in manufacturing industries, while Singapore tends to promote the technology-intensive goods production skipping over the capital-intensive goods production. The next followers are the so-called ASEAN countries - Thailand, Malaysia, the Philippines, and Indonesia. Even in this group, the industrial development differs due to the government intervention. Thailand, and Malaysia seem to have followed in the footsteps of Singapore, while the Philippines and Indonesia seem to catch-up slowly.

Evidence shows that the late-industrializing economies have followed in the footsteps of the early-industrializing economies in industrial upgrading. To verify this hypothesis, I test by tracing shifts of RCA curves and estimating non-parametric Spearman's rank correlation coefficient. This implies that there exists a regional linkage of industrial development in the sense that there have been shifts in comparative advantage from one country to another.

I go further to examine whether Vietnam joined the regional dynamism by calculating RCA of Vietnam over the period 1991-1999. The evidence shows that though Vietnam joined the regional dynamism, Vietnam has untapped her comparative advantage due to wrong selection of industries to protect..

I further point out the potential comparative advantage for Vietnam and find that there is no linkage between potential comparative advantage and the trade policies. The trade policy of Vietnam has centered on the industries in which she has already had a comparative advantage rather than on those of potential comparative advantage. This policy may cause the potential industries to collapse once Vietnam fully integrates with advanced ASEAN members. The regional integration should be taken into serious consideration so as the collapse of potential industries would be avoided. Trade policy changes should be made to achieve this end. 


\author{
Abbreviations \\ AFTA: ASEAN Free Trade Agreement. \\ ASEAN: Association of South East Asian Nations. \\ CIE: Center for International Economics. \\ CLMV: Cambodia, Laos, Myanmar, and Vietnam. \\ CPC: catching-up product cycle. \\ ERP: Effective Rate of Protection. \\ FDI: Foreign Direct Investment. \\ HKN: Hong Kong. \\ IDN: Indonesia. \\ JPN: Japan.
}


KOR: Korea.

M: Import

MLS: Malaysia.

NIEs: New Industrialized Economies.

PLP: the Philippines.

RCA: Revealed Comparative Advantage.

RCC: Rank Correlation Coefficient.

SGP: Singapore.

SITC: Standard International Trade Classification.

THL: Thailand.

TWN: Taiwan.

$\mathrm{X}$ : Export.

\section{References}

Aghion, P. Howitt, P. (1998). 'Endogenous Growth Theory’. MIT.

Akamatsu, K. (1961). 'A theory of unbalanced growth in the world economy'. Weltwirtschaftliches Archiv.

Blomqvist, H.C. (1996). 'The flying geese model of regional development'. Journal of the Asia-Pacific Economy 2: 215-31

Deardoff, A.V. (1999). 'Pattern of trade and growth across cones'. Available at www.spp.umich.edu/rsie/workingpapers/wp.html,

Dowling, M., Cheang, C.T. (2000). 'Shifting comparative advantage in Asia: new tests of the 'flying geese' model'. Journal of Asian Economics 11: 443-63.

James, W., Movshuk, O. (2003). 'A comparative advantage in Japan, Korea and Taiwan between 1980 and 1999: testing for convergence and implications for closer economic relations’, Developing Economies, 3:287-308.

Jomo, K.S. (2002). 'Rethinking the role of government policy in Southeast Asia' Oxford Press. 
Kojima, K. (2000). 'The flying geese model of Asian economic development: origin, theoretical extensions, and regional policy implications'. Journal of Asia Economics 11: $375-401$

Kosai, Y., Tran, V.T. (1994). 'Japan and Industrialization in Asia - An essay in memory of Dr. Saburo Okita’. Journal of Asian Economics 5: 166-176

KWAN, C.H. (2002). The rise of China and Asia's flying-geese pattern of economic development: an empirical analysis based on US import statistics.

Morishima, M. (1996). ‘Dynamic economic theory’. Cambridge University

Okuda, S. (2000). 'Industrial linkage and Direct Investment in APEC'. APEC study center, Institute of Developing Economies

Hiratsuka, D. (2003). 'Competitiveness of ASEAN and Japan'. IDE Institute Research paper.

Parker, S. (2002). 'Did East-Asian developing economies lose export competitiveness in the Pre-Crisis 1990s: assessing East-Asian export performance from 1980 to 1996', ADB Institute Research Paper, 34

Urata, S. (2002). 'Emergence of an FDI-trade nexus and economic growth in East Asia'. Oxford Press.

Vernon, R. (1996). 'International investment and international trade in the product cycle'. The Quarterly Journal of Economics, 190-207.

Yamazawa, I. (1990). 'Economic Development and International Trade, the Japanese Model'. The East-West Center, Hawaii,

Yamazawa, I., et al, (1993). 'Dynamic interdependence among the Asia-Pacific economies. The Keizai Bunseki, EPA.

Yun, C. (2000). 'A Critical Review for the Flying Geese Pattern of Development in East Asia’. Yamaguchi University. 
Appendix 1: RCA of Vietnam, Thailand, Indonesia (1999)

\begin{tabular}{lrrr}
\hline SITC Commodity & \multicolumn{1}{c}{ V } & THL & IDN \\
\hline \hline 1. Primary Products & 8.99 & 0.72 & 5.21 \\
33Petroleum, petroleum products and related materials & 8.99 & 0.72 & 5.21 \\
2. Natural resource intensive products & 1.90 & 1.34 & 2.48 \\
27Crude fertilizers and crude materials & 0.48 & 1.66 & 0.56 \\
28Metalliforrous ores and metal scrap & 0.29 & 0.14 & 3.87 \\
32Coal, coke and briquettes & 2.35 & 0.00 & 7.59 \\
34Gas, natural and manufactured & 0.04 & 0.26 & 9.16 \\
68Non- ferrous metals & na & na & na \\
97Gold- non monetary & 0.02 & 0.24 & 0.80 \\
24Cork and wood & 0.18 & 0.63 & 1.39 \\
25Pulp and waste paper & 0.00 & 0.33 & 0.90 \\
63Cork and wood manufactures (exl. Furniture) & 3.31 & 0.54 & 2.82 \\
64Paper, paperboard & 0.72 & 1.04 & 11.00 \\
5Vegetables and fruit & 1.15 & 0.52 & 2.18 \\
6Sugar, sugar preparations and honey & 0.10 & 1.73 & 0.56 \\
7Coffee, tea, cocoa, spices, manufactures thereof & 23.24 & 3.86 & 0.46 \\
11Beverages & 0.08 & 0.23 & 4.46
\end{tabular}


23 Crude rubber

OLive animals chiefly for food

1Meat and meat preparations

2Dairy products and eggs

3Fish, fish preparations

21Hides, skins and furskins raw

29Crude animal and vegetable materials

43A nimal, vegetable oil processed

94A nimals, N.E.S.

4Cereals and cereal preparations

8Feeding stuff for animals

9 Miscel. edible products and preparations

12T obacco and tobacco manufactures

220 il seeds and oleaginous fruit

26T extile fibers (expect wool tops) and their wastes

41Animal oil and fats

42Fixed vegetable oils, fats and waxes

\section{Labor- Intensive}

66Non- metallic mineral manufactures, N.E.S

82Furniture and parts thereof

83T ravel goods, handbags and similar containers

84Articles of Apparel and clothing accessories

85Footwear

89Miscellaneous manufactured articles, N.E.S.

93Special transactions and commo. not classified to kind

96Coin (other than gold) not being legal tender

\section{Capital- Intensive}

510rganic chemicals

52 Inorganic chemicals

53Dyeing tanning and coloring materials

54 Medical and pharmaceutical products

55Essential oils and perfume materials, toilet. cleansing mat.

56Fertilizers manufactured

57Plastic Materials

58Artifi. resins., plastic Mat., cellulose esters/others

59 Chemical materials and products N.E.S.

61Leather, leather Manuf., N.E.S. and Dressed fur skins

62Rubber manufactures, N.E.S.

65Textile Yarn, fabrics, made- up art. related products

67 Iron and steel

$\begin{array}{rrr}1.92 & 0.26 & 0.05 \\ 0.22 & 12.42 & 10.73 \\ 0.63 & 0.39 & 0.39 \\ 0.71 & 1.47 & 0.04 \\ 16.32 & 0.16 & 0.07 \\ 0.07 & 7.80 & 3.49 \\ 2.63 & 0.03 & 0.09 \\ 0.01 & 0.57 & 0.45 \\ 0.00 & 0.92 & 4.62 \\ 8.62 & 3.49 & 0.11 \\ 0.08 & 1.22 & 0.50 \\ 1.84 & 1.61 & 1.15 \\ 0.13 & 0.23 & 1.00 \\ 1.28 & 0.08 & 0.15 \\ 0.19 & 1.02 & 0.54 \\ 0.00 & 0.06 & 0.04 \\ 0.33 & 0.22 & 9.53 \\ 2.17 & 1.16 & 1.23 \\ 0.60 & 1.14 & 0.64 \\ 0.99 & 1.41 & 2.46 \\ 3.10 & 2.70 & 1.02 \\ 3.97 & 1.67 & 2.24 \\ 15.85 & 1.93 & 4.34 \\ 0.51 & 1.28 & 0.72 \\ 0.40 & 0.00 & 0.00 \\ 0.42 & 0.01 & 0.05 \\ 0.30 & 0.67 & 0.75 \\ 0.14 & 0.42 & 0.79 \\ 0.05 & 0.26 & 0.30 \\ 0.03 & 0.28 & 0.29 \\ 0.02 & 0.09 & 0.08 \\ 0.54 & 0.51 & 0.73 \\ 0.06 & 0.12 & 1.27 \\ 0.01 & 1.03 & 0.50 \\ \text { na } & \text { na } & \text { na } \\ 0.27 & 0.62 & 0.27 \\ 0.18 & 1.53 & 0.35 \\ 0.37 & 1.20 & 0.79 \\ 1.14 & 1.11 & 2.21 \\ 0.09 & 0.41 & 0.40\end{array}$


69Manufactures of metal, N.E.S.

$0.28 \quad 0.65 \quad 0.45$

81 Sanitary, Plumbing, heating and lighting fixtures

$\begin{array}{lll}0.15 & 0.91 & 0.61\end{array}$

5. Technology- intensive

$\begin{array}{lll}0.19 & 0.97 & 0.27\end{array}$

71Power generating machinery and equipment

$\begin{array}{lll}0.13 & 0.59 & 0.22\end{array}$

72Machinery specialized for particular industries

$\begin{array}{lll}0.16 & 0.14 & 0.11\end{array}$

73Metal working machinery

$\begin{array}{lll}0.01 & 0.24 & 0.05\end{array}$

74General industrial machinery and equipment and parts

$\begin{array}{lll}0.07 & 0.78 & 0.12\end{array}$

750 ffice machines and automatic data processing equipment

$\begin{array}{lll}0.62 & 2.41 & 0.43\end{array}$

76Telecommunications and sound recording apparatus

$\begin{array}{lll}0.15 & 1.16 & 0.68\end{array}$

77Electrical machinery, apparatus and appliances

$0.23 \quad 1.46 \quad 0.30$

78Road vehicles (inl. air cushion vehicles)

$0.05 \quad 0.34 \quad 0.09$

790ther transport equipment

$\begin{array}{lll}0.13 & 0.05 & 0.09\end{array}$

87Professional, Scientific and controlling instruments

$0.07 \quad 0.55 \quad 0.30$

88Photographic apparatus, optical goods watches

$0.19 \quad \underline{1.62} \quad 0.89$

95Armed fighting vehicles, Arms of war

na $\mathrm{Na}$ na

Source: calculated by author from IDE database and Vietnam's General Statistics Office 